をの記しこ稿議るきは、デる

场号

ちで・言う会論的にかかルン稿

うはノ語ち生及と、にれケボの

る、リはで活範な記すに!リ目

のあモ、、の囲っ号るお㕕代的

でらノ象む中にて学作けの㕕は

あゆ余徴つで関い乞業る貢をる

るる点やとは等るセ艺方献あデ

事器記を象る、通ンをつュ

項㐫号精徴か象才しボみかル

导と練やぎ徴口てリいうケ

音穵し等記りた㛬ズだこ!

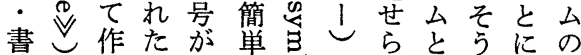

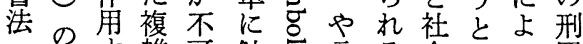

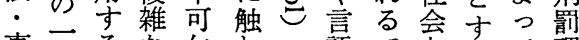
事亏るな欠放と語でなるて理

物に諸表なて記哲あいする論 身す多示\&掠学ろしも社や 身ず形のきき式とたう社の会宗 りな式はしい骂にこ会あ的理

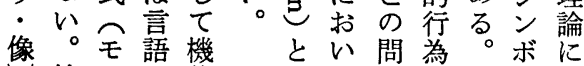
社りで能のて題とこル展 が会不あし 区多にのの論開 意的にるて 分少と連こ一さ 味なよ。いをを関こ般れ

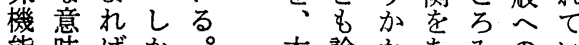

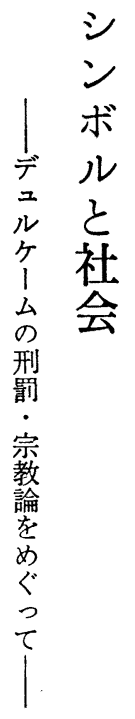
能味ばか

本論かあみのい

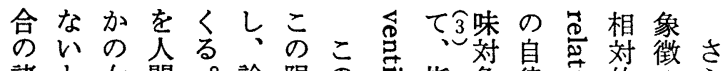
諸と女間。論、限の苍指象律富的令ら 項主は理こ理り よ总摘意性の的に恣サに 示守味のこ見おに哥杂間きと性ボン

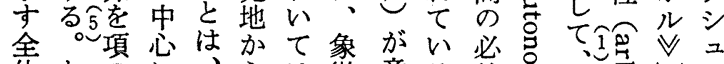

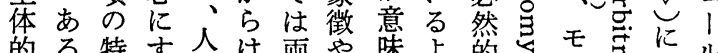

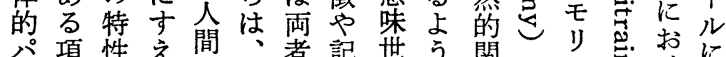

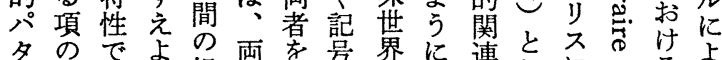

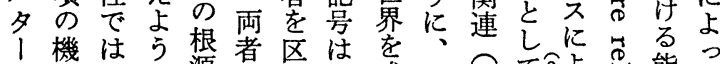

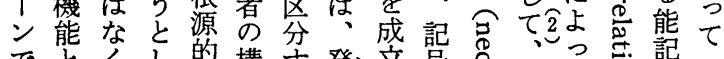
で文し的構守発立号员八て匛記

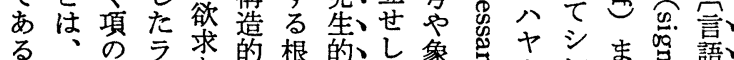

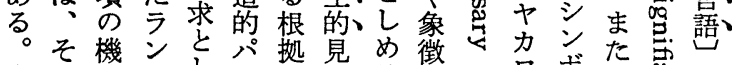

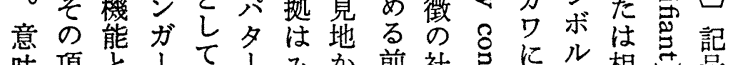

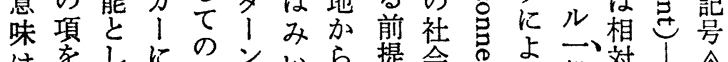

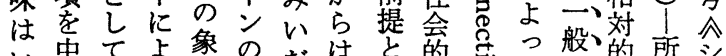
い中てょ象のだは共な的导て般的所芯

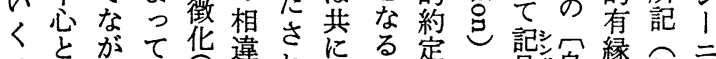
うとがて货違れにる。定し記号自縁の二

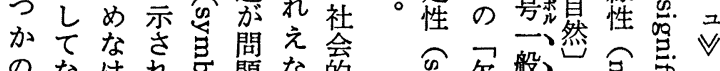

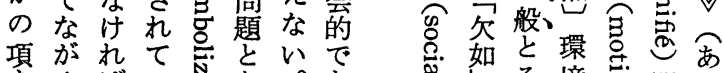

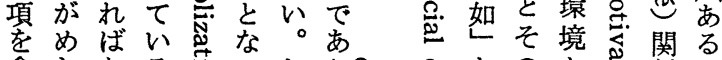

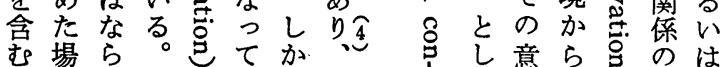




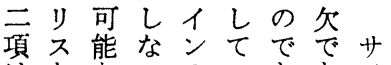
はなないののああへイ ど\&な対こるる买ン と行のら、象れ動と杜 に主な一対のイイ能 自義る対す項ンンに 然的でとるをとはは 的記あし作使対主三 な号万て用用象体つ 事学う相|す大にの 象に。関|るは対夕 なお自打第一し।

以然る介主対々厶 しる的三人者一の

状る記項すとの対 況シ号つるし相象主 にグ年。て関を体 属ナナイこの関告 てルチンの主係知サ お ラ対合がなすさ り、場茾象も記てる 通合イはし号お壱象 常こ已相主作り、气

サれ|にが|- 矛が 150 交存 対 不
な差シ会ルをイサ伝すえルと意が ら異ン的と提ンイ達るるがき味、

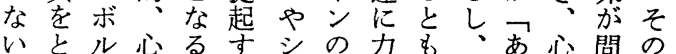

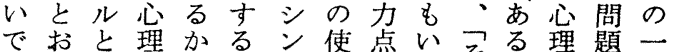

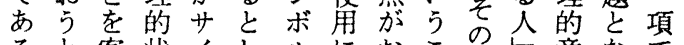
ろと客状イしルにおこん意なで

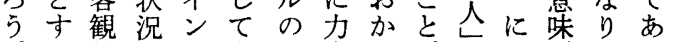
る的にとも主点れがが対が、る なに左な、体が後でかしうまサ ら区右るあに㧤き者き加たイ 、別さかるよかのる攵あび主ン そすれれは項るれ心。るあ体や のるる、自使て理前シ対がへシ 論こた主へ用い的者ン象っサン

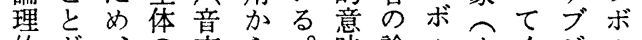
的が、の声ら。味論ルオく流ル 意で心お・生社の理しブるエを 味き理か身势会場的にジ呵ク中 のな的れぶる学合意よエたト心 差い意てり種、、味っクとしに 異。味い・名心主のてトえとな にそにる事の理体場つこばいが もこも特象結学に合そをてうめ とでと定な果のよ滰あ項た う両うのど驾領る客対意るをと か者き歴政域シ観象味種中き なの茾史が要でン的产すの心、 け根イ的シなはボなをるシと論 れ本ン、ン問、ル意意とンす理 ば的と社ボ題サや味味いボる的

象る対。术用＼cjkstart関記るのて要象で知知作ぎもては です象○一来を右係号。出知なと人覚覚角なよくこ あのを方にものはとた発覚事の為る丕可怔いいるの

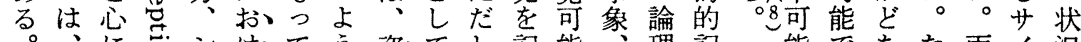

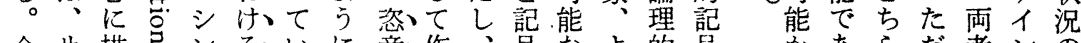

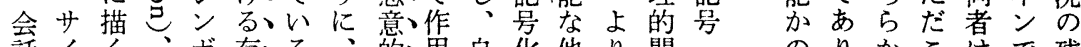
話イく、ボ存るる、的用自化他り関つのりかこはで残 にンよ対ル在。自な髙しの興係令い、ののそあ余 おのう象。气記然相る的、事味は、 ず他項関れつ部 いよに|機き号的関よ記救象深自テ方に係自て分 てうさ能究は記関う号急をい然ィ汃所を体をを あにせをは蛋号係なと車人事的フ る対る必、塗、に部異の為象記 1 人象も要四物人士分なサ的亡号 シ がそのとつをいあ為ぎでりイに相のヤ ᄀのですの指るる的なは、レ創関場ル ナもある夕示い記いなこン出関 合サ ポのる10。। 寸いは号。いれは係とイ

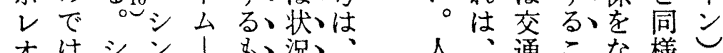
オはシン|る況、人、通こな様し ンなンボの、のい為あ事とすでの レくボル主で、ず的る故がとあ場 と、ルは体あ、過れ記状のでこる合 い対が主、る去も

象、体シ 。莫 語に直ををン現通 をつ接導ボ在す 発いにいル ある 尔て 意て、る記 るの味そ表 い号 と表导の象は作 号況発き乃。歹 点尘る。生る。 そ残妾。任間記 のり意汽意は号 対の味笛的文 象部しはでよそ と分て列ありの でい属主とよ記 あっす体しい号 るそる㠰てし化 が知合用自雷る 主覚がす然鳴部 体し現る的吕分 にが実だな稻で とたにけ相妻あ つい生で関のる てか它あ関光 興、てる係つ稲 味あく。をた妻 のるるすなサは あいのなしイ雷 るははわてン鳴 とま、ち、での きつ一、るあま だた方記にっこ のの以車つ重対 
図 I

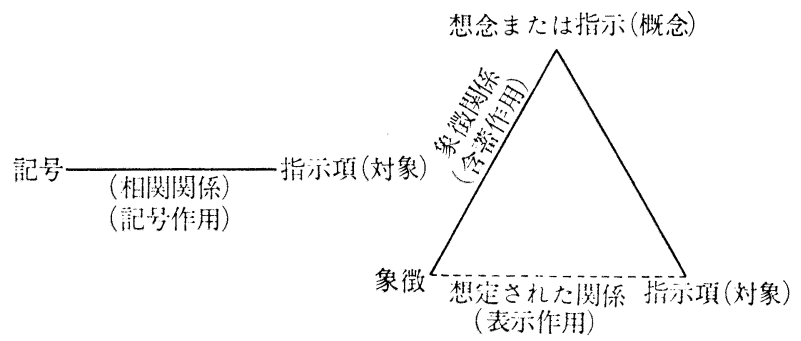

裐兰場合さ 1 本分

』ル徵際いる形オの

は場になでにグサ

怘想の介いあよデイ

怘省前入がろっンン

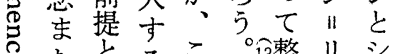

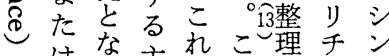

にはな主らの守ヤボ

媒指て体の図る!

介示いが項になズと

さきる。記索はらのの
いつので ジせき

ば、通るฏル゙、相

も常。はだは

の、、し、ナ

のこかそ、゚ポ

なのしのレレ

か、概、対才オ

の、念 シ 象ンン

普、はンののが

遍、個ボ代こ眼

人理々前

（）内はランガーの用誈

る存パ表こをではが 在夕にれもは、で し1共らつああま なン通がこるるる。 けとに佉とが二る゙ る。

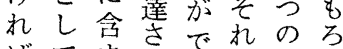
ばてま机きぞ対も なのれるきれ象ろ ら公てたる異にの な共いめけなっ個 以的るに机っい人 の概基はどたて的 で念本、も表適主 ミ的がでをに 私真はお居 的なるもる 的運〈い加 な連方文の 表も対がよ ร. 象の象く 5 としはにたに ๖て概つけ敬 で具念いで礼 あ体 ていあす る代化 § のろ る とさ赫。う い杂焉老つな うてこ運まこ こおで峛りと あ夯的諸、象切体とり、あむ、、は

を、しに体に記がう像接るがシンオラなボ係にて もンてサよが先号、。徽に一表实ジグンゔルつ結指 ちが構イふふ介行とこま場指方示代ラデガけの宁び示 、現成ンて入しにのたの示、すルイン|ら対すつ項

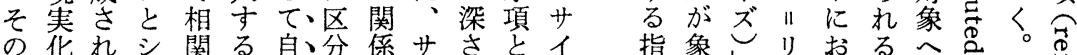

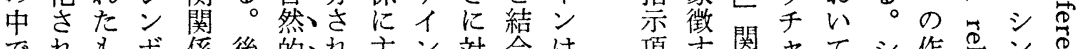

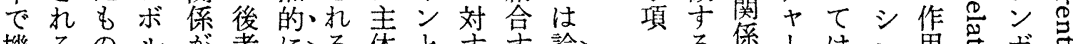
機るのルが者にる体と卞守論合る係、はン用壳ボさ 能ででと成で存でが対るる理、 しああの立は在あ介象、。的、 てろり、論す、し、ろ入立ここ極、 いう。、理る社てう。しは項れ限

万。具 的

加体区

万以的分

でうなは あの 意 る。味あ

し両場ま か者でで しとはも なも両純 が社者粋 ら会のな 論生中パ 理 活間夕 的 $k$ 的 I に起パン は源夕と
社会标的はに

会り、前く対な山拉

的、者る—記元い

圭こで段の号がて

主のは階相場指は

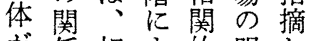
が係相よ的明し指 はを関っ対るいて示 じ発関て応さい め見係自関とる概 汃しは然係よよ念 ら使只的をびう 介社記なう流を 入守会号な 5 を るる際的少てで項ず る際主為いあ的、 と主体的るろな直
対、と六含ボはす

象あ替に蓄ルホ、竞 とい定よ作がラでそこ 以は机て用概ガり指は

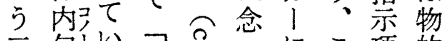
二刨い方员にこ項的 つ守る。寻表よのと対 のる 意想こボ总象て折間に 味念のル意に表し接限 対心がさ対示た的定 象概う指でし作関関さ を念に示市角係係れ

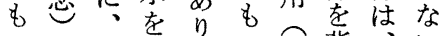
つとシ象?つ令背、以 てとシ象こ直号後想 るシボすの接芯を主と のンルる関作寈つ机間 でボはっ係用さシた接 あル、シははとン関的 


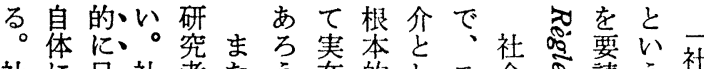
社に呈社者たう在的しモ会施請 $う$ 社

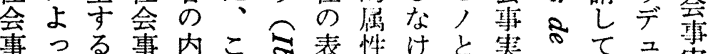

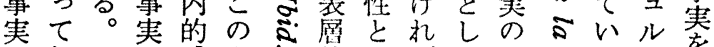
は個そは感よう的緊ばて、 ᄀ人れ心情う?な密なの説 自意は理やな 万識個的意外 のの人事图的 本外意実と表 性に識には示 を法をく独が 変規支ら立科 え、配 ベし学 る統しすた的 こ計てぐ客手 と数いれ観が な学るて性 か $く$ とがこ を 自てえよたな ら構にうなり 結成、なな 晶さ自客れる 炛れら観れだた しるの性ばめ らの力をなに るでそ自りらは 特あれ生な
今。なら社明 心の相な会亦 を関い事心゙ 手関。実き が係そが内 かに $L$ \& 的 りよてつ特 とつ、な性 して社ん注 て結会ら 基ば現かそ 的七机市 なおこ覚ま もりの可で の、外能は

をこ的な観 確の特外察 定こ徵的で きと現示な

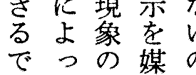

る。

站ᄀ出 モ実官 そ ミ゙ は義 観のと 察第 ᄂ

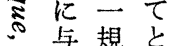
光準り 名らはあ れ、つ のるかか すすれわ ๙べにな $\stackrel{2}{2}$ け 岁でるれば 西イ゙な 츤 使い 氕角使以 るン人ら

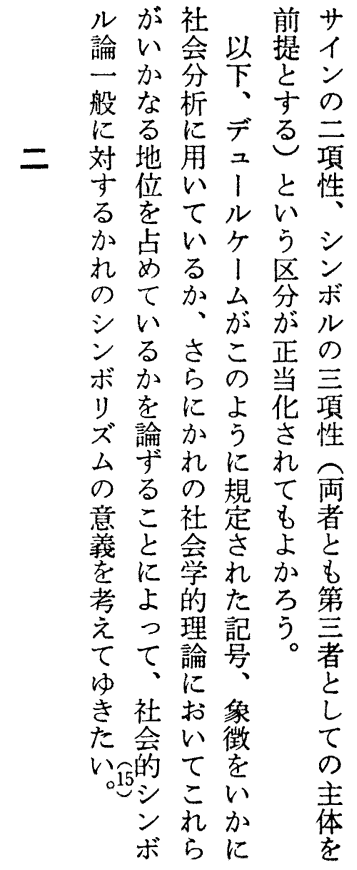

ルが社前サ 一汃分市之至 般な析、手の 対地用二可項 す位い儿兄性 か占いケうシ れめる। 区ン のてかム分ホ ンるさこ正の ボからの当三 リをによ化項 ズ論かうさ性 の元の規て車 意こ社定も者 義之会さよ と 考上的たろ第 えて理論う。竞 き社お象它 た会い街て い的てをの シ厹か 主 ボらに
が法工同帯者の連

連規ルじのがつ带社 帯尔状変同水と会 のと I 況化じ銀法連 いいムのと物の規带 わうは事は理昇とは ば、自、象客体降い不 自、然研に観采边可 然的究属的にと三避 的な主しな属こつ的 記、相体て対しののに 号、関汃以応て液事組 と関らる関 $心$ 体実織 し係もる係るの分さ て索行命をる野れ 最発為なう熱はた 適見主さしにの共法 で、体 尺、状変的 あ、利加両法態的形 る用ら?者規態 、すむ心は則と相を とる独同の品関と 考こ立?巳数因関る えとし範量果係 たにてし疇の的にそ のよい。の変にあれ でつるつモ化相るゆ あて、連りな社関。え た法带、゙い会、蓆社

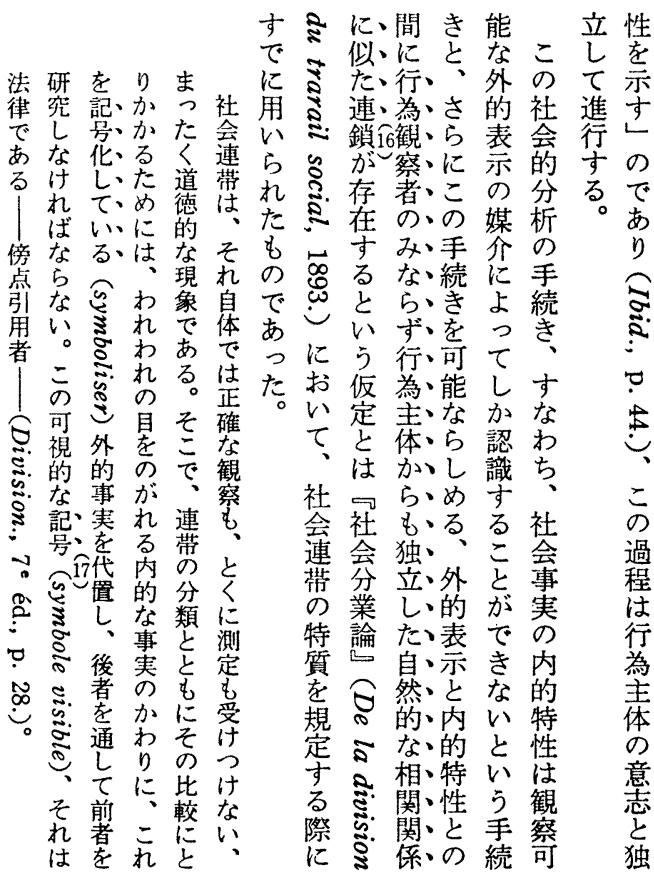


指いも個はた制うすの出をヶが嫢はに前りた法

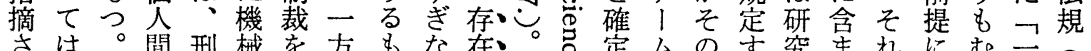

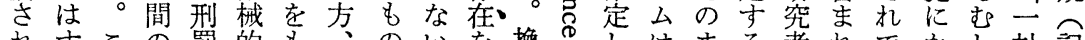
れ寸この罰的毛の、を換のしはまる者れでかし対記 てべの異と連つ分と。前言るよ形にるはれろ总

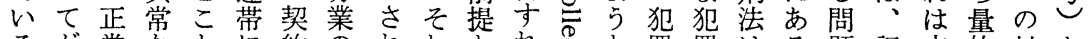
るが常なとに約のれれとれんと罪罪はる題記立的対と 上契な法なと法発た沖すばをしのを機種は号紊応連

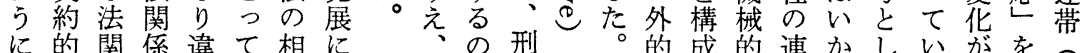
に的関係違て相に、の刑。的成的連かしいがをて

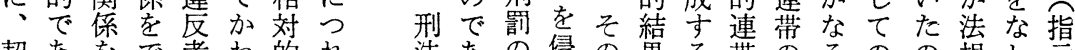
契あをで者わ的机法あの侵の果る带のるのの嫢し宗 約る規きにる增、 そる定る苦有加刑 れと卞だ痛機唯法 自はるけや的みの 体か子正不連ら減 はぎの常名带れ少 当らがな誉を、に 事な契法老記こと 者、約関与号れ?

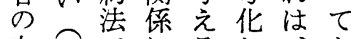
自にでにるし尔 由市回亩て集少

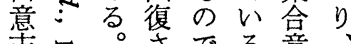
意り。突でる。意原 多契るなこ識原 どさ約機たの優回 くとおをだ裁し的 のり発等結で、を存す 法で則て項 相、動す果あと記在の規あの打

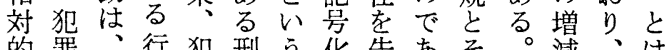
的罪、行犯刑 5 化告あ之。減、は 減行機為罪罚性乙知了のをこ息 少為械では制質てすう記媒の然

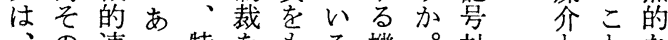
の連る特をもる機。対ととな 集も带と定手口。能記象乙相 合のの結社がてこを号年てら関 意は根論会加心の有, 連測連関

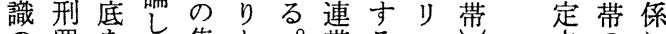
の罰をた集と。帯るモ管さのに 弱登な合しそは。文机質う

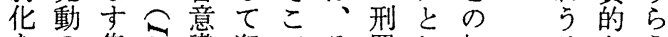

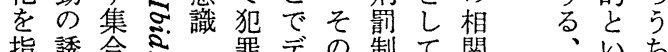

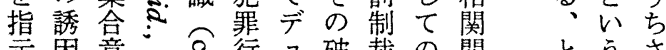

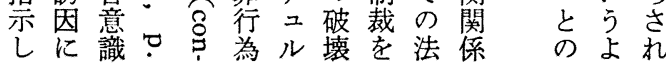

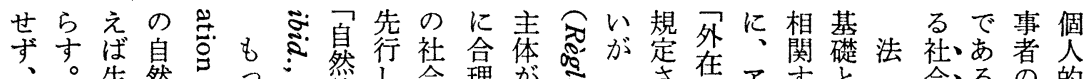

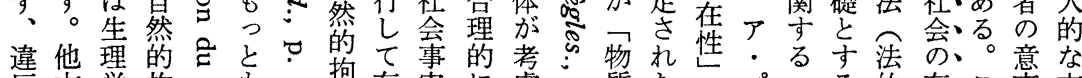

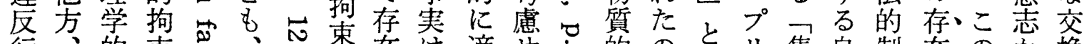

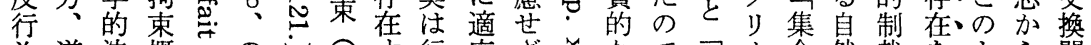

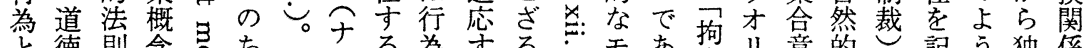

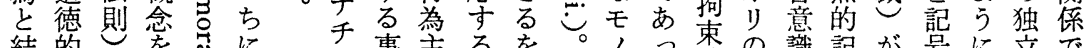
結的を毛事主るを。ノっ束の識記が号に立で

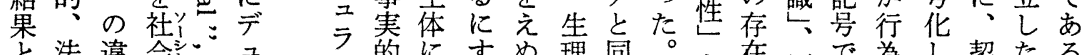

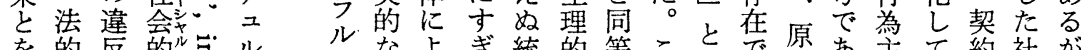

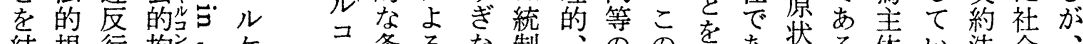

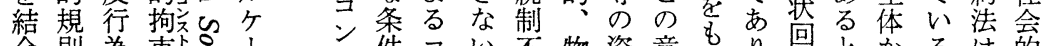

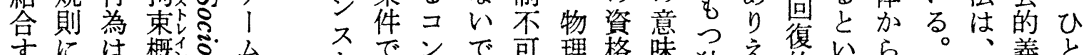
守には概灾么年でンで可理格味独え復いら。、義と

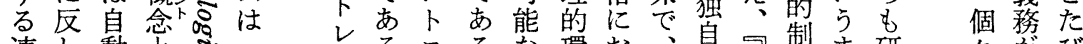

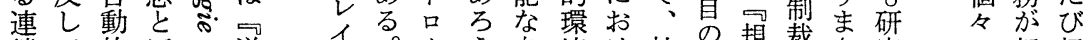
鎖て的区。道社替裁さ究の契契 出を江別德 介不事 在そ定て宗実 しののいすの

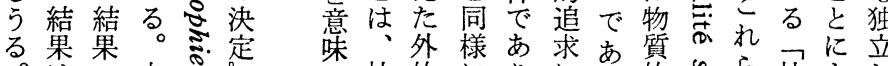

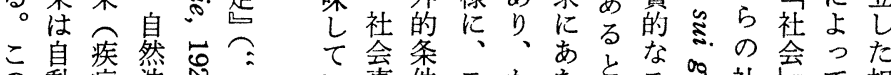

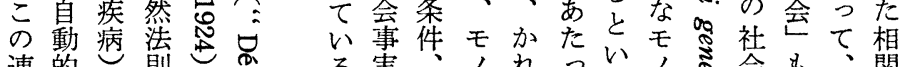

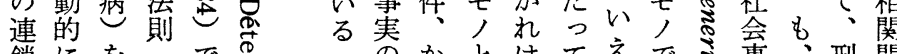

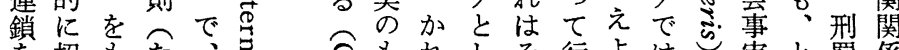

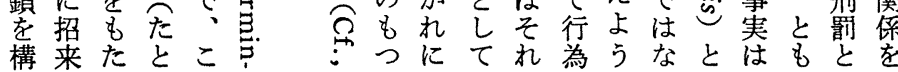

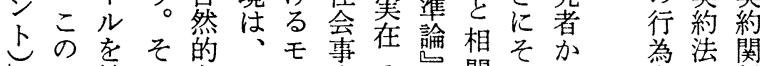

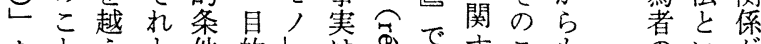

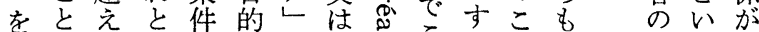
特 う成 定 形 立 のでし 意強た 志制な にさら 


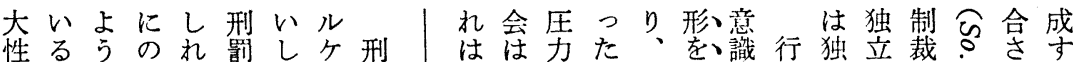

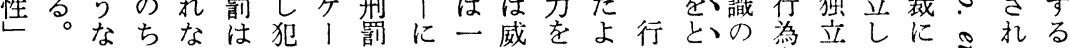
でな功にいつ罪厶制も種嚇警う為つま者してよたたも はる利の。犯性の裁とのと告に観てま注ているる結の

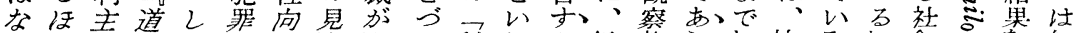
くど義德か反を地社い利うる行者らあ社るわ会り老な

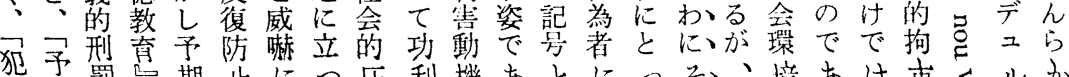
翡防罪心期止につ圧利機あとにっ之、境あは束安ルか

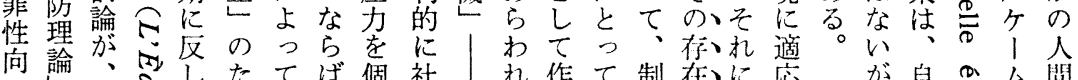

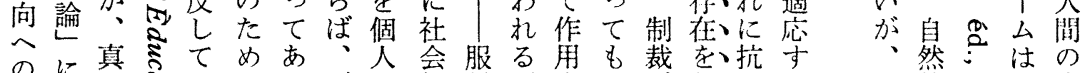

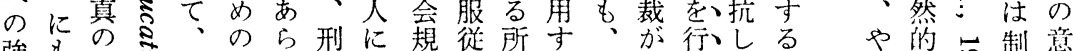

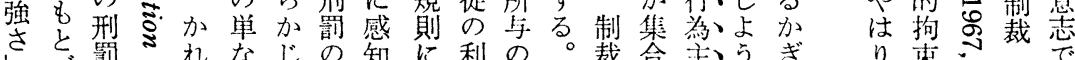

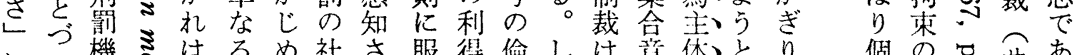

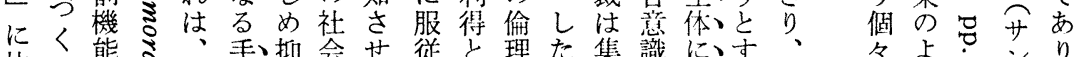

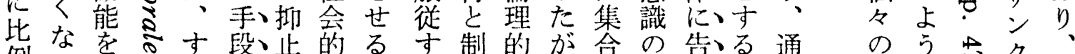

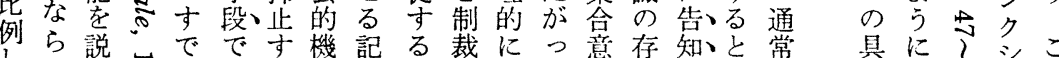

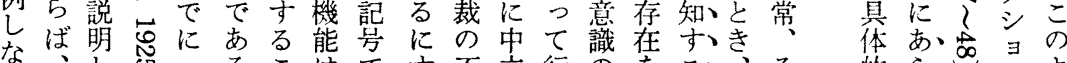

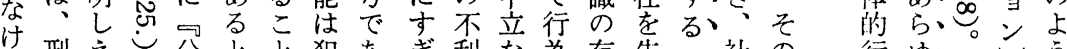
け刑之し分とと犯あぎ利な為存告の社の行ゆ、。己う 机罚なに業みで品るな益条者在知で会存、為るししにに なはい打論なあ行、いと件にな市あは在者人からし

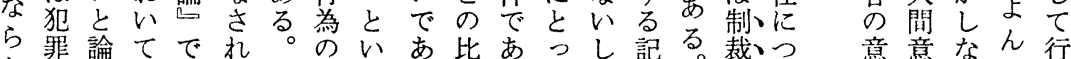

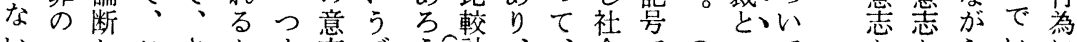
いᄀしこさかま䓌デ518計、、会でついて加らいに

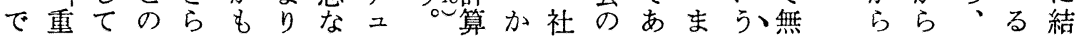

わ刑りの犯構意、ここあ的工要で合罚刑度合いあ

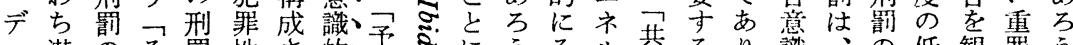
二潜のそ罰性さ的予防にうそル共るり識方低観罪う

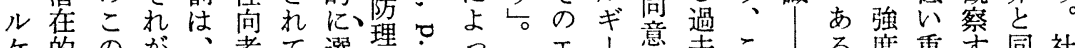
ケ的のが、者て選埋?つ、エ、意去こ|る度重等同社

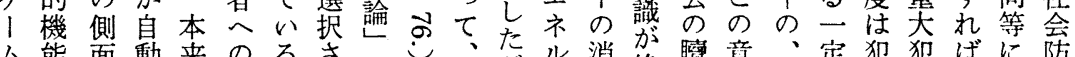

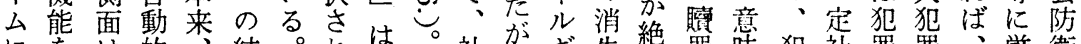
にをは的結。れは社がギ失絶罪味犯社罪罪、䇥衛

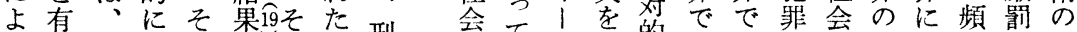

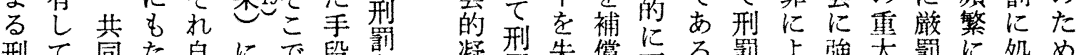

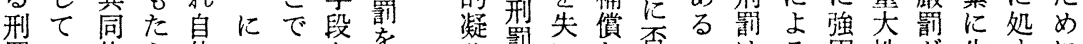
罰い体ら体つこと学 のる20連すにい替僦おて理な社 潜滞効おて理な会 在再角い語論し食

機強意はて刑本体

能化識䍜、思具少に

のとしきるの的站よ

発 以てわ。顕な”っ

見少いめ在貝社

は意なて方的的社 意心非、機 "会

そさ、合情能手衛

の机理動段衛

ま 妨的的犯図を

結京激反罪式目

刑果情動者に的

罰导的とな立と

のすゅでしいう

シ な

集颜以し歪

を真之岕さ

確县々 5 さ

固機のと結しる

と能愁なと

しは桀き

た共社っ共

も基会た共

の意連ら体

に識到ばの

すの の 、情

る生弛 共動

氛緩同的

と茄意反

で維生識動

で持 ずはが

あする必こ

るるで然の
はる固性が生すに

す、冒にに課ずるは 組顿根比せるの . 織、う例ら微 が頻 さにいしれ罪好度 れ対てててに都の

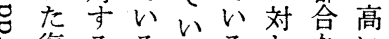
復るるるるしない 心隽社道るのての微 〉行会德のがはで翡 会為会意で普厳あを 側識あ通篙るま 社加なるで加。れ 会らい。あ課だに がのしそるせがし 犯感感れ。ら、机 翡情情ゆつれ刑お

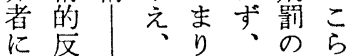
强動集刑、頻度な 


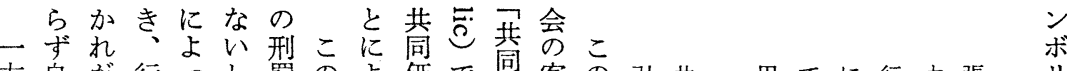

方自が行つし羅のよ価で体客の引共用てに行す張り

動社為てつは状っ值あ体観よ用意罚者確集為るし共ッ 象的会者、モ研況てにるる゙的 う者識と固合に全な同ク 徴に規もこ, 究を、対と变存に|架は否的よ員け意な

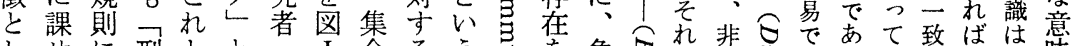

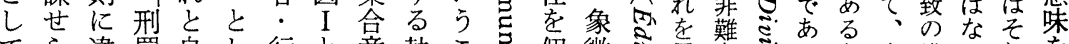

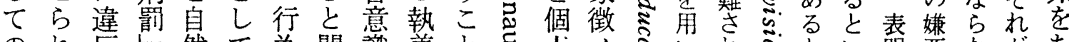
のれ反乚然て為関識着とこ人,ミいれらと明㯖ながあ

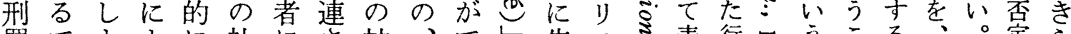
罰でよよに社にさ神、でし告モミ表行りうこるる。定ら

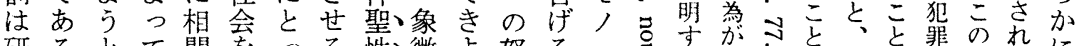

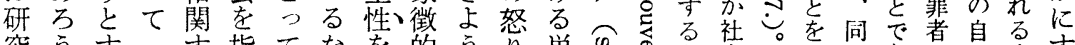

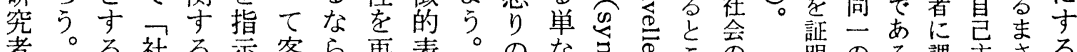
者。る社る宗客ら再表。のな寻空会掯のる課主さる

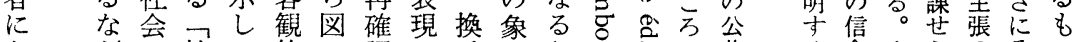

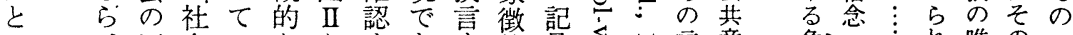

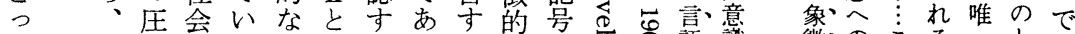
て制力のる外なるるれ表で怘語、識

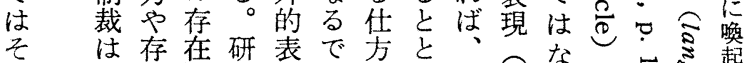

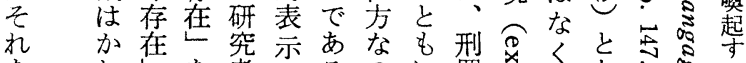

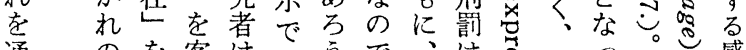

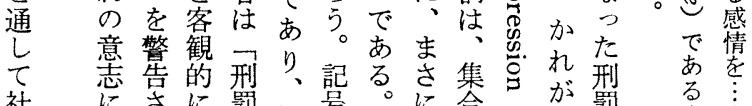

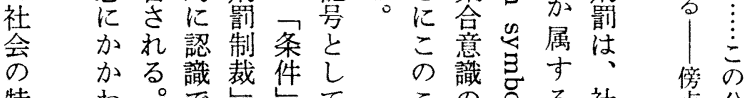

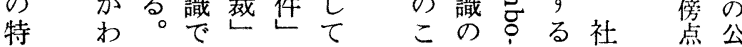
徴の諸苦の竞あ ๙. 精苦痛手にる。 令神痛に段お

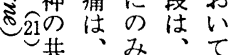
で成集存犯 、 あ一合在 罪 決 る 致的しが然 感うた管 依情古索自 点とつ正喚老

映定のなこ保も・り体、象情り行表為主なはあ質

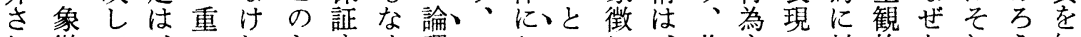
れ徴て、大れたすく理こおこに、共主で対的なれう知 てといま性ばめるば华れいるよ刑同体あす共らは。る

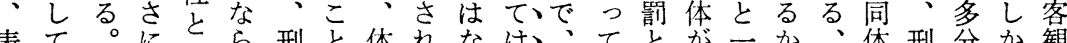
表て。ににら刑と体れなは、てと元かか、体刑分か観 示の当比す、罰怔験なん漠こ表い全体ら共の罰にし的 対刑該例っのでのけら然の現う員とで同根は主、な 象罰社例こ諸き持れか然共さむ二なあ体源、観行手 は会てれ段な続ばのし同机つ致っる。的行的為が

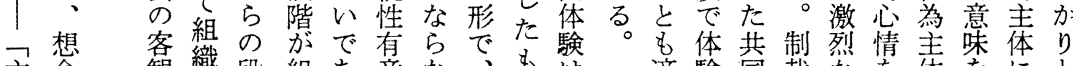
主念観織段組あ意な、も政適験同裁な亚体をにと 観的さ階織ろ味い客のそ、合し体主怒冒ををとな 的な机はさう性。観でれ、的たで体り势含つっる 共価る冒れ。老さ化あ自小な感あはの行む。てで

同 客值す瀆

験华化空衣

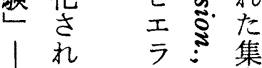

と共 キ? 侖

象茼 ! 体 情

徴 験 価。強

意」值こ固

味采段文

的に学階冒

に媒反設瀆

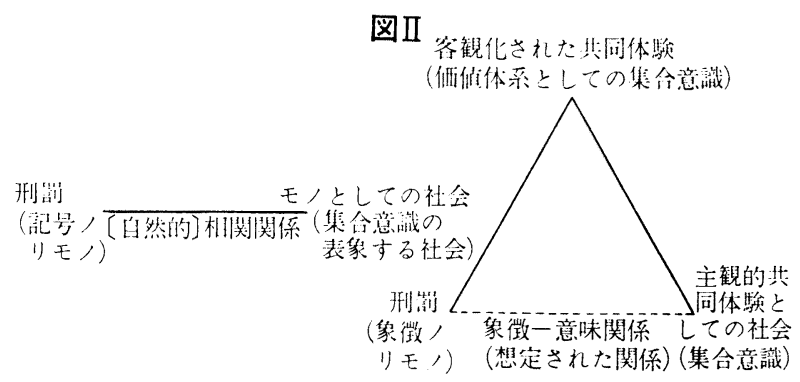




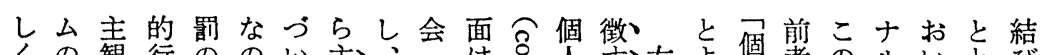

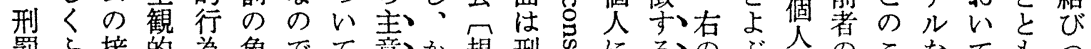

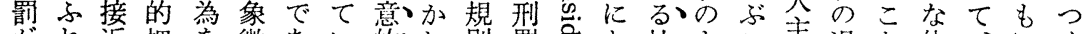
がれ近把を徴あい的れ則劍密と社よこ主過と体、にく

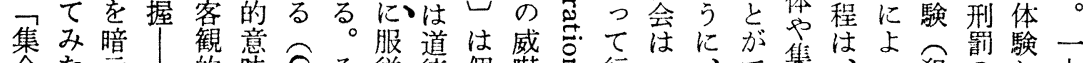

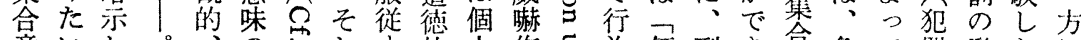

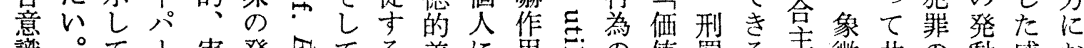

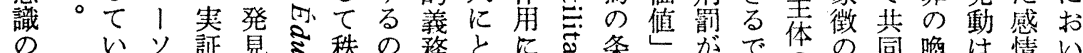

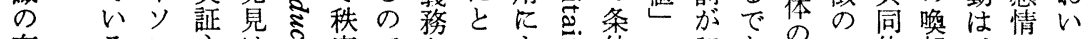

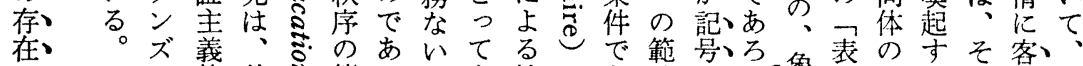

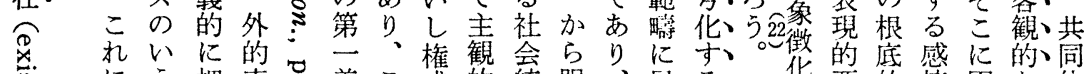
济に5把表? 義こ威的統服、属る、华要的情固な、体

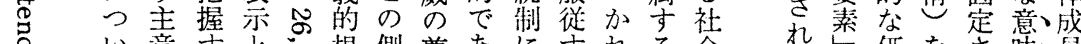

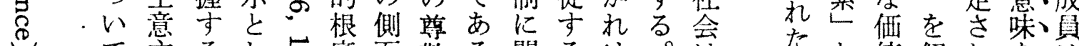

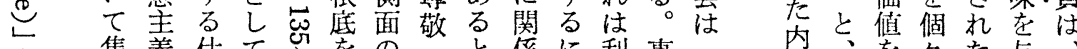

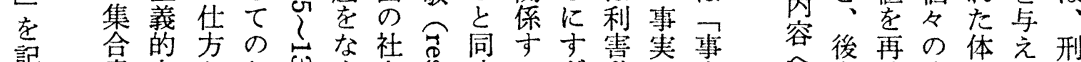

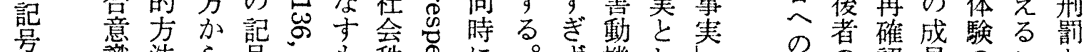

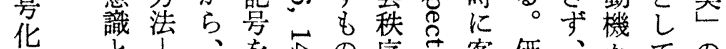

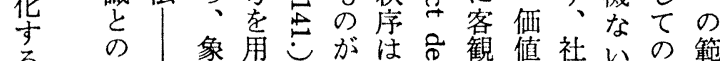

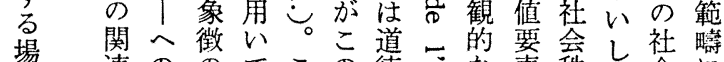

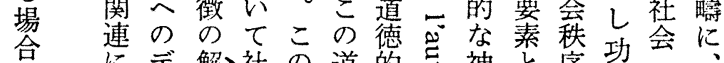

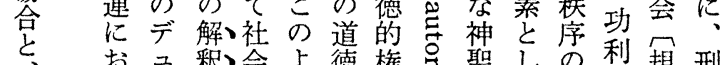

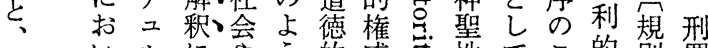

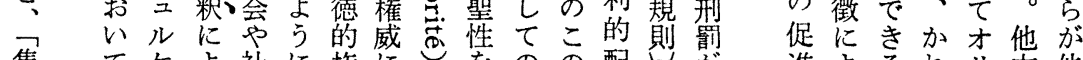

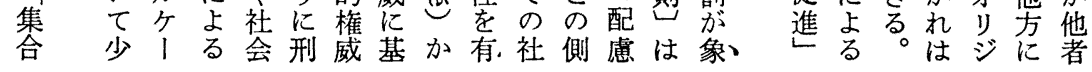

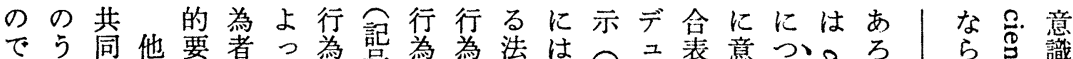

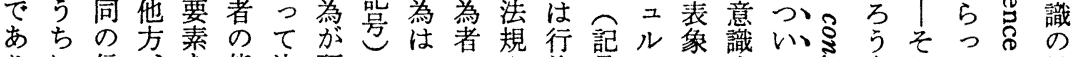

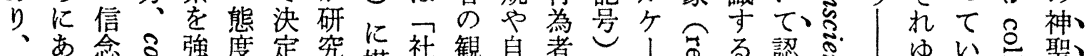

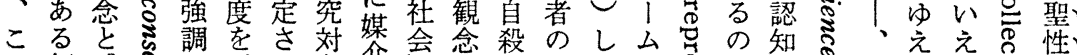

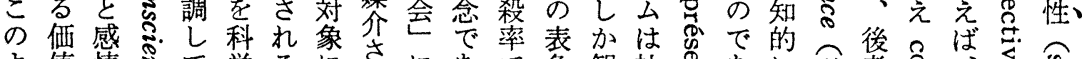

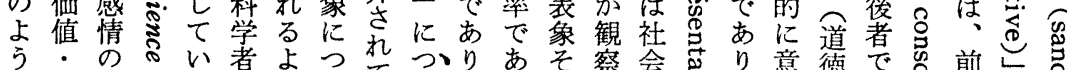

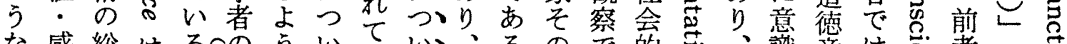

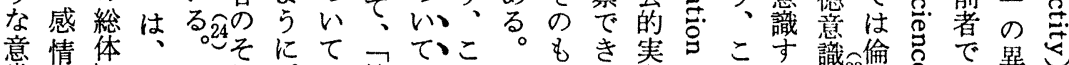

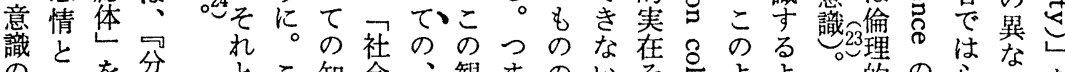

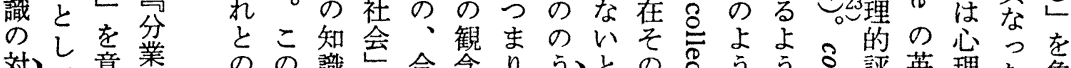

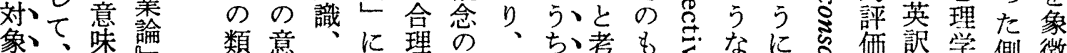

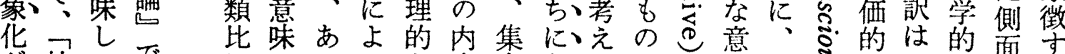
が社てで定にでるっな容合あたは識行密側っ 面る シ会い定よ゙、て 義表り直での為面念認問場

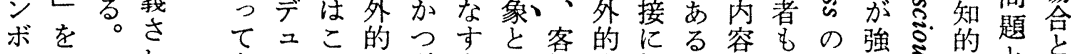
ルいこれ のわのた 媒ばい場 介 即、合 同 に自、一 上的行 社 つに為 会 て意者に な識はお さす自け れるらる 考ルのに科もは観表観合茕外場調密側と先 えケ対決学の外示察命構的合さ的页面さは 行㕕をさに記的は記き守会科て意強る。集 為䒠指れ検号世研号ず究するに学い意蚂。集

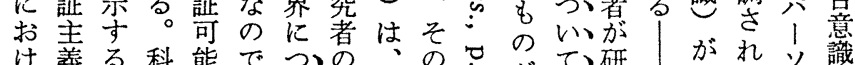

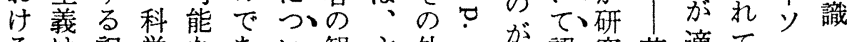
るは記学なあい観主外メが、認究英適てンこ 認、号者知るて漈観的怘知対訳当お无

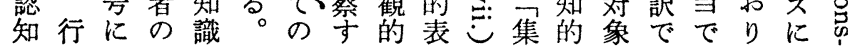




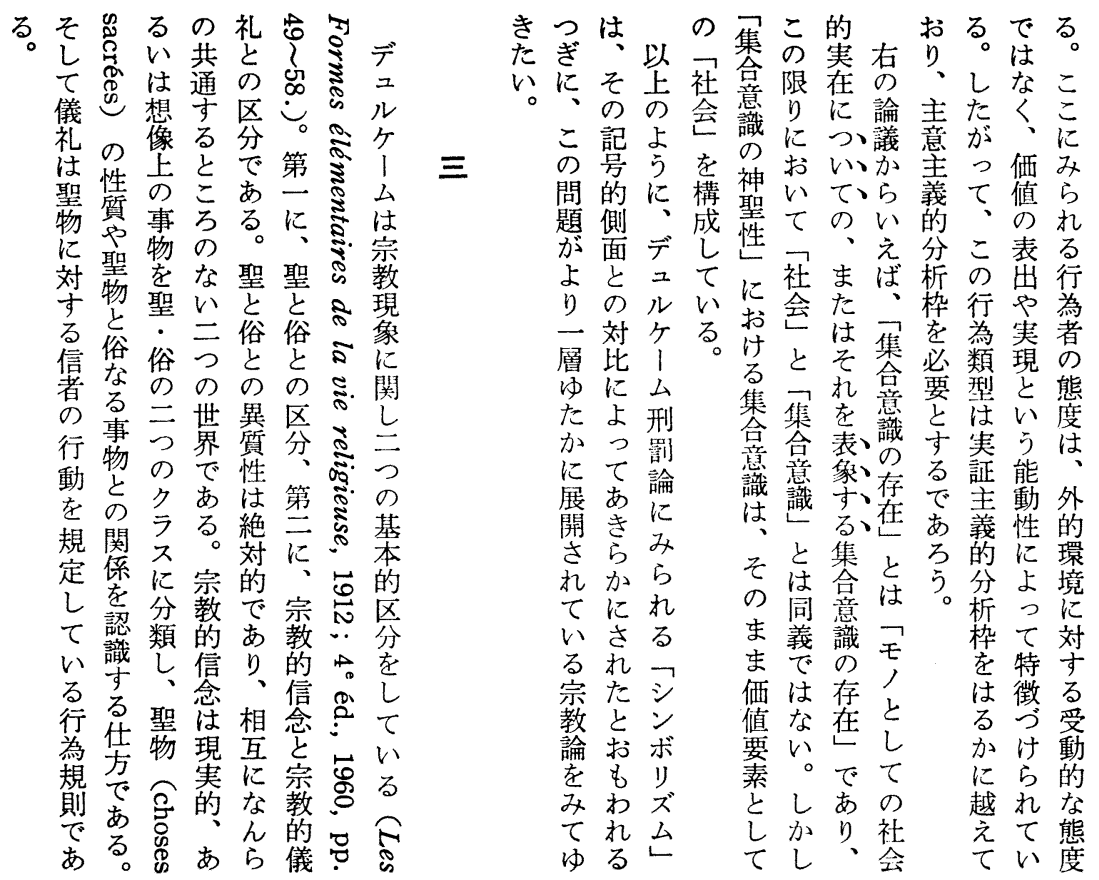

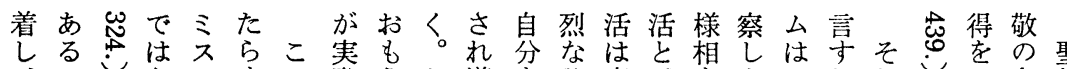

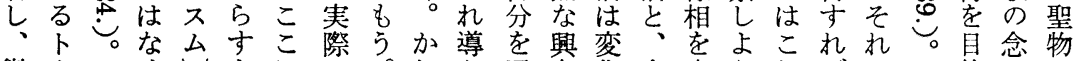
徽、宗くしょに。机通隻华宗交亏机ばで的でに

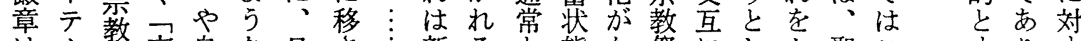
は厶势忘自な日さ 新ると態な祭にし卜聖こすすす 聖の験我然原常れ㐫たのこ箱く礼くた、物のる、る

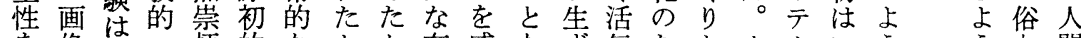

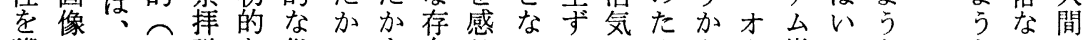
獲つ祭王説な俗のも在心っるにめえ|崇かななるの

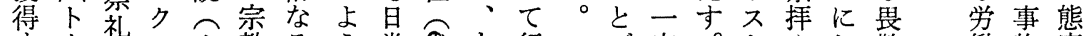

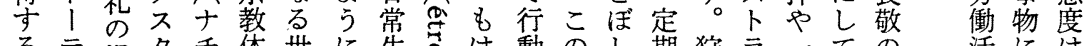
る。場夕千体世に生のは動のし期狩ラ一ての活には

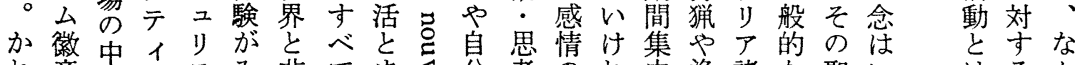

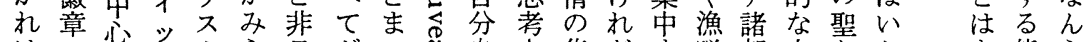

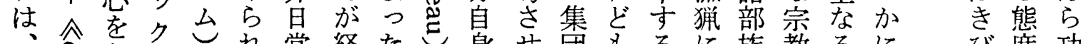

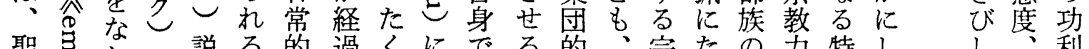

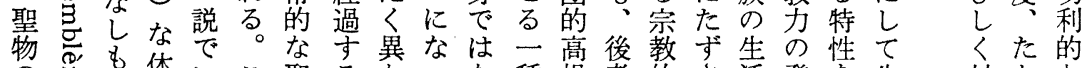
の念す体いこ聖るなっな種揚者的さ活発を生対とな

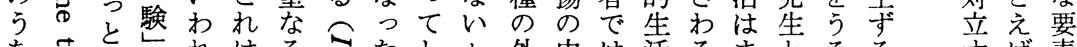
与索てれはるるたと外中は活るまとるる亲ば素 第灾もでる精世㣽特ま々的に集と分っのののる日も

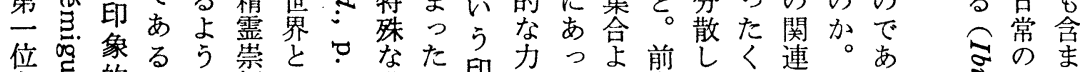

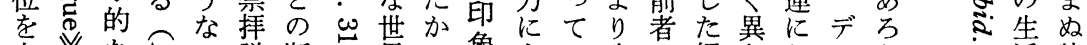
点

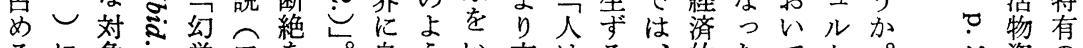

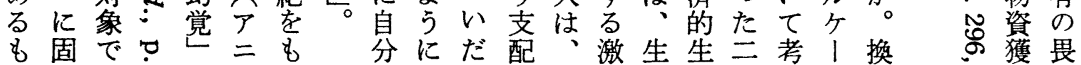




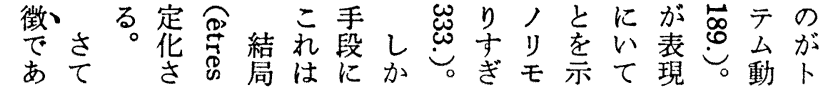

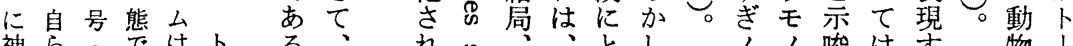

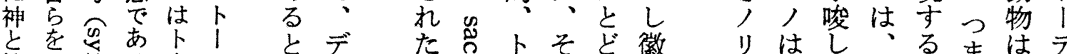

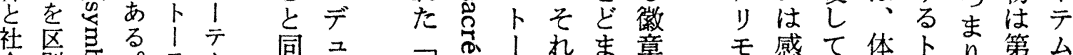

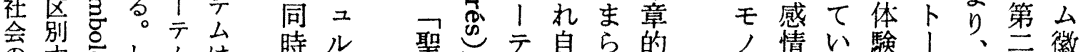

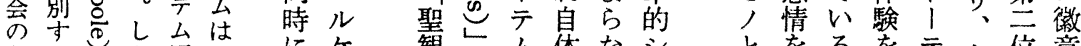
象る加原三観么体なシ とをるをテ卜位章 徵たでし理重、、念と徽、いンしし明の表么!をで めあ、な劣学感。ボ確でわ種テ占あ

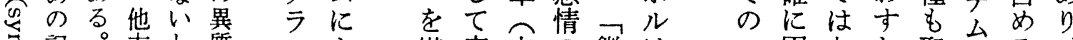
寻記。方し質ンよ媒客宗の徽は 号号占的集れ仝観教構章宗

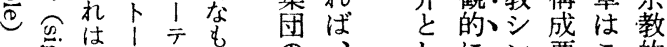
で吅テムの の、しにン要こ的 あ厄゙ム神を記卜て意ボ素の体 るでンはと表号、宗味ルで感験 とあ゙のクよ系でテ 教ゔあ情感 るる旗 ラんし むム体けはる老情

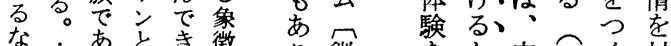
らうあと徵り徽ををと宗るく対

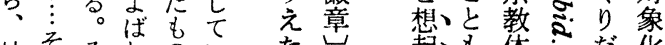
神そそ饥のいた岂起も体たた化 とこれるのる。さは験?すす 社では確外。 会卜芼定的市 は点氐族た感で 一厶加社賞 $つ$ が相 会的卜 に同至会時な記形

ト、、を它のる

1 るシさ岕にた

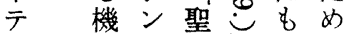

ム能ボなし役の

神学ルる 立単

の有に存寺固在

便固なた聖徽る

宜定加め物䉪にそ 性华ろにと草机 性すう類な聖ぎが 石か像り性な幾 欠に。的う㨞い何 けはなシる付、学 る余ぜンの年と的 かりなボでさ指線 らにらルあ指画 でも動がるて摘に あ複物最。いしし る雑植藡こるていつ ○様物あはらる描 ななる、こ出 ๖様どと宗そるす方

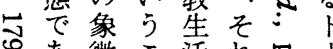
も徴こ活れ?

华し秘る 徵はは学にのるで刑た章にラ仕義れし 学て性こか索こ、の科対。、罚め山所方的るてこ

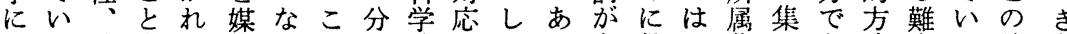
よる後をは仝ぜの析的関かる自役、集団あ法点な論な つ。者批々科よに記俰しト然立氏団のっはをい述い てしで判アし学うた㞻を、、贸う族を存た記示。にの いかは $L=て$ 的なえしな両テ記記成他在。号しこあて ずし自てミ表に記うのし者么号号貝のをそをてのきな れな然いス現分号る意、にをでなが集告れ介いこらか はが現るムさ析が経味同お自あの複団知ゆしるとかろ 説ら象。やれで同験作一い己つで雑とすえて。はのう 明夢の前ナなき時的用のてのたあな識る゙モす、よか さは神者チけるに実驾経は記のる集別機記了で社う れ心秘でュれ経宗在可験と号と气団さ能号とに会に

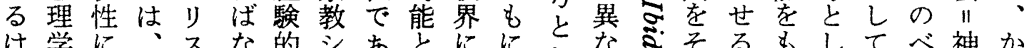

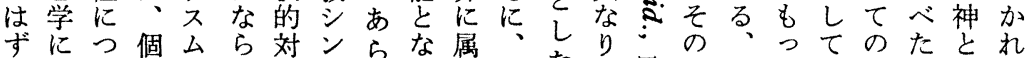
でよい人がな象ボねるし記た、?具シての社よいは あっての宗いがルね゙たて号とあ岕体ルおト会うう記 るての心教の記ではめいといる导的シりりのにか号 崇理をで号あなにるそう氏过統で、テ存、れを

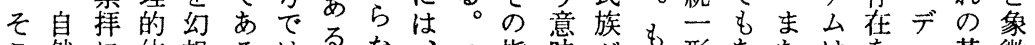
こ然に体想ろはるな指味がも形あたは悬徽 で的よ験にうな老い指ま示であろ態る。研科ル本と 、秩っ、もかく考。示り対人るんと究学尔的を こ序てつと程 れは宗まうわた二象記と的楚こて1はににム、極 ら物教りかざ。ルが号は記史こ表テ集一認のゼ的 の理考夢せ わそケ寒会号的䭪象公定知実にに 神学説のて ざ机、証々対で時場す壬成の証含区 秘、明神い象でム科く—あ点合る徽員クる主京別 


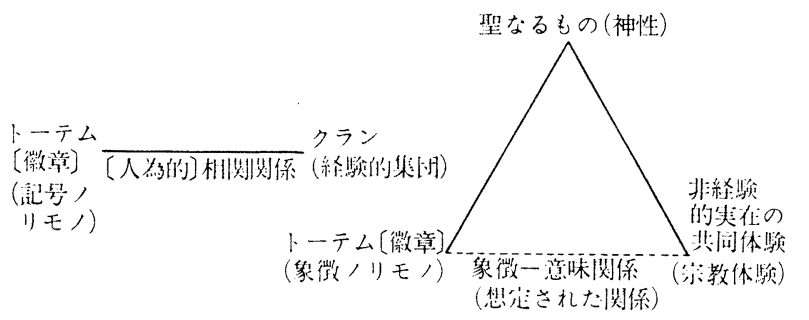

き の対 て性 るこ存象説㤎 経の在で明消 験よであさ隇 的うあるれし 実にる個えた 在、人なあ のデミミ物いで 歪ル: 理ミ官

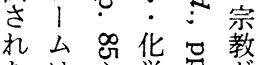
たは学?架 て 非气。活いい子あでに示身る、団。現宗対认続

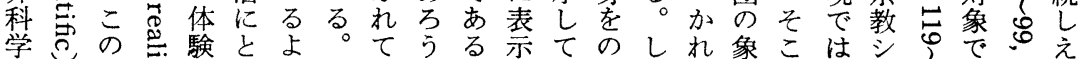

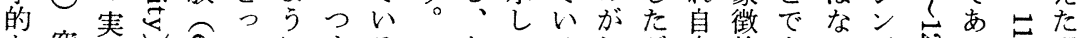
な究在されてにまることてるれが身的もいボ产る节理

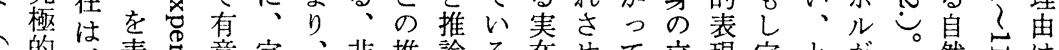

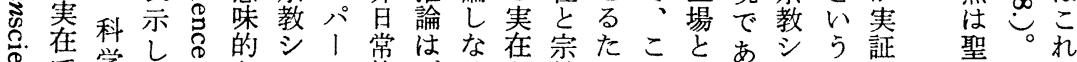

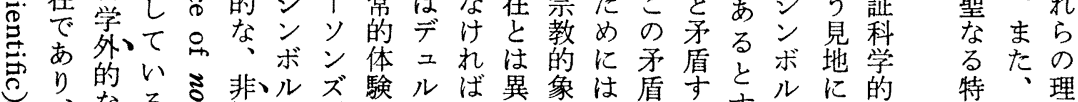
包り的いる゙非ルズ験ルば異象は盾夺とルに的特、理

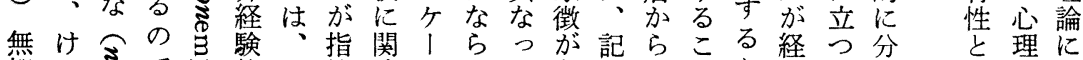

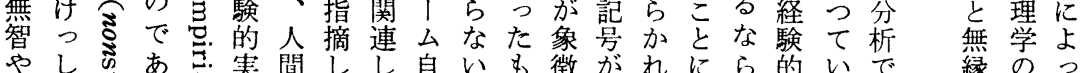
やし它あ実間しし自いも徴がれにら的いで緣のっ

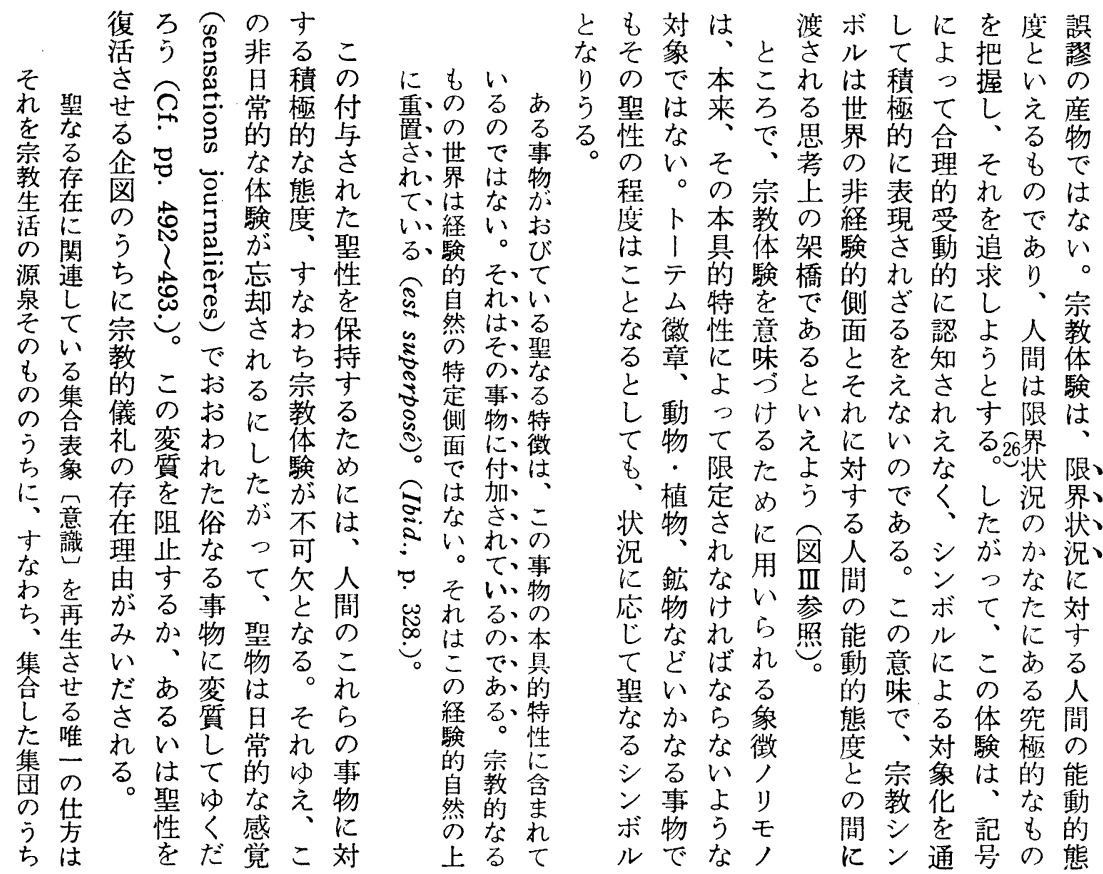




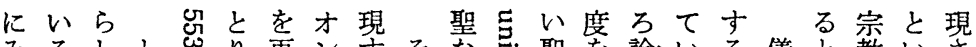
みるしし らのたか。わ確でるれるさ物客理る信礼い体うれ初

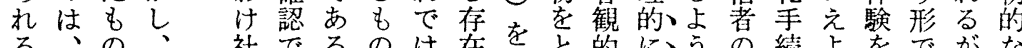

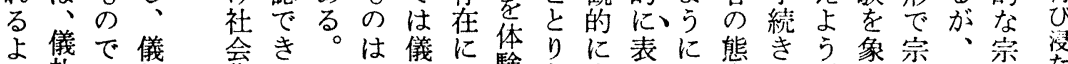

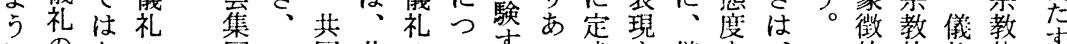
にのなの団こ同共のいする式梦儀を、 、基いこ吕の体同社てるか化る礼明聖

卜本潜の周よは体会のこうしもは確物

光的在客期 $う こ の$ 的集とこての宗にに

テ 形 的 観

厶 態機的

種と能な

のしで結

繁てあ果

殖の模る。

以擬 加参

$亏$ 的机加

日儀ら者

常礼 が が

的 意明

な突識確

的にの究機合がといで教組具

にしコ極能意ざにるあ感織体

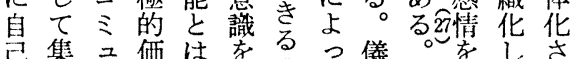

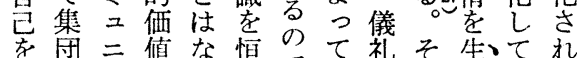

的的礼体

に体は験

表験、はで

現をこ聖

寸再のな

る現シるる

独すシホシ ミ

再の才とん众で聖参れ理おて

ののルボ。

確連言てで的あるな乫は的り、い

シでをル

ンあ操に

すが介のろ更こもはな表こ聖

る再し聖う新この、る出のな

手強てな加しと定も恶る

経他的に

済三に意

段华集る。よよのめのる味を

でさ団も儀うう䨝らにとでの

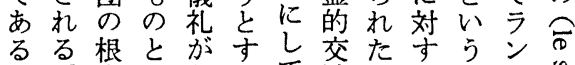

的芺目図

效要的 ᄂ

果管とて

な゙导しをを

る 。根と

す交交すすう主るす

ボる作よ

身しるて

振㤂と思

りっに考

シ ‘ょし

ボ義てい

ル礼行 号

儀气きき間もがす

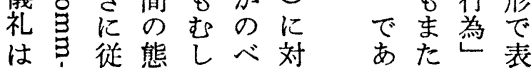

れ礼る生記

こる的。産号模

のと身さ力と擬

よこ振ら要な 的

うろりに素る儀

ににが、はの礼

由意因、では

呪来識果儀あ宗

術守的連礼る教

はるに鎖で体

望の体図験

原苾験 IV の

初机然さ参象

的た性れ照徵

因繁はた 。的

律殖道德因表現

を 德的果加

指 5 的集律ら

示結集合含転

す 果合力拿华

と連の顕れ

之関外現て因

を的とい果

にな表しる律

操す現て非を

作とで表人指

ᄂ 想あ象格示

像るさ的す

卜さ儀れなる
化さ

にせ数

よる似

てた む

-

つが

の度類

然成

法さも

則れの

とるを

なと、生

たそ衣

吉儀 う

礼 原

的 理

当源

染明

。脱確

乙 宗

種 教

の 的

自欲

生的求

般坴
て右支徳こ存 ! 徳だなな能ちる るのて共にのム效、則ほ有

母5 同上貝種果相的 胎 5 る体っ体のに像繁、てテ儀 とにののて的繁よ的殖こいム礼 も儀で凝こ象殖つなとのる種は な礼あ集の徴とて物一儀との るはるを存という的致礼、様類 宗へも在しうら効しは主態似 教るたとて直う果所周観をの 的贾 らのの接 5 に期期的模 6 象:士コト的さ関の的に做の 徵导よミ1なれ籿物に信尔が でり うュテ機てる的挙じる類 あ 厉な二厶能い信効行らこ似 る象才種にる念果されとの が心徴ンをつ。はをれでも 灾的をでいつ、もるいその ま导機可きてま儀たのるのを た。能能るのり礼らで繁生 そ驾なだ信、がす、ミ殖み

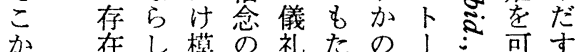
らしめ倣背にらよテす能と 呪、結し後抒すう厶守ない 術こ果よにい現に種のらう

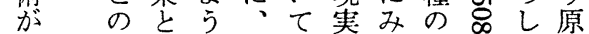
生信しと聖は的え自まめ理

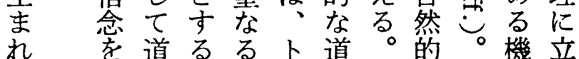


会会る。し 行 ム

行にこの者観

為対の社に念

のすよ会と論

実る 5 自っ

証場な研ての

羙合社究賭律 転

的同会是的

観様会行なみ

点にに為客ら

と、対 社 觀 れ

観認すの性る

念知る意をで

論的行志有あれ観品を識い体記い原必うに果儀さギ、। 的受為吕しろて念\&超論る系号る初然と立律礼ら的テ

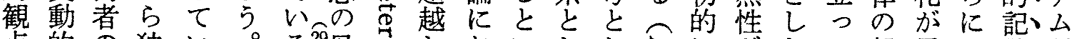
点的の独い。る29母矛しおいししるに尔たて起思号種 とで熊立たモ。胎いえててミは範。社原考デとの

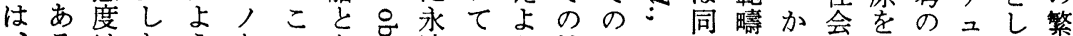
るはたうとこな而遠はう社口?-のれ学な範ルて殖

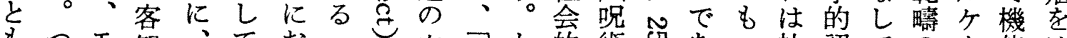

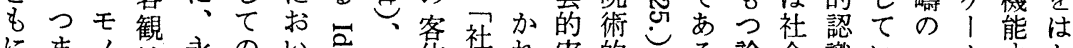
にま人性永のい邑個体社れ実的。る論会識い一ム立加 行りと性社て 個世会の在山っ、理の論るつはるる

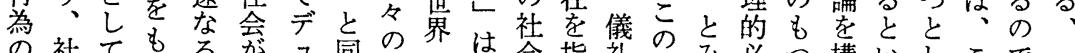
の社てもる分二同の特会指礼意み必つ構いしこで一 能会のつ客研ル特々経学示は意な然道想うてのあ種

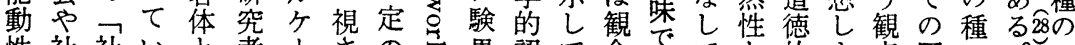
性社社いと者、さの界認て念でてと的よ点因の称、

とかち っにそそ て関のれ い係象で か亦徴 は なる的 るの 側 刑 意か面罰 義さ壳聖 \& 号物 $\supset K$ 的.

$\tau こ$ 側 儀 いの面礼 る三との の 側 は意 で面、味 あのデ | ろ関つ二機 う連、ル能 かはケに シ ンムけ ボのる ル理三 の 論 重 問 的 性 題 立

二場す 般とな にいわ
四

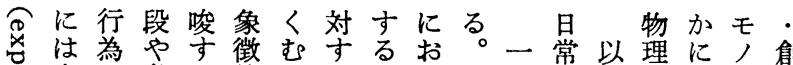
実。条る的畏る態いこ方的上的加も造 总存 $气$ 件 \&行敬合度ての文なの記か力性 长に寻なの為の理は体究こ社よ号わテ

加吉で 念的俗験極れ会 $う$ や らゴす

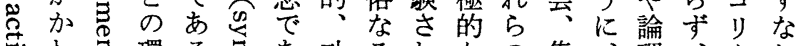

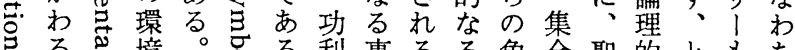
るる境。する。利事るる象合聖的ともち で価气的記气。的物。方徴表物記も主

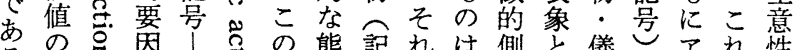
るのさ因行韋の態記れは側と儀〕アれ性

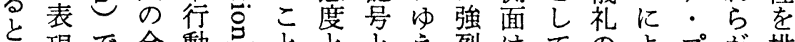
人現で合動ことととえ烈はてのよプが排 えそあ理はと族異し人な究の記っリ個除 るれり、的、の30、なて宗集極観号て才人年 だ自、認記間記り、の教合的念的認リのて 万体象識号に号、卜的意な体側知に心い う徽をに明 |な、識な采面さ存性る 等的得よ確行んテンのるをはれ在のと 目行るつな動らムボ活を指、うし外い 的為とてな動加に動の示モるて部う

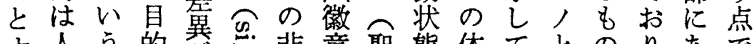
す人う的巷品非章聖態体てとのりあで る間意追あ它合山物つ験いしで記る類 表の味求あ宮理や聖をるてあ号か似 現生でにこ高的、儀な表。のる。た 経て

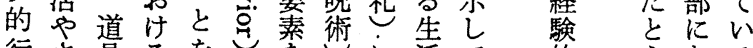

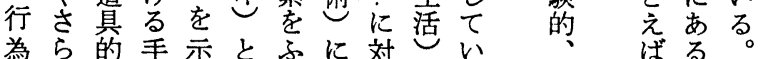


で会はで為に表に作観能まの握ノ会ノのなはれ学

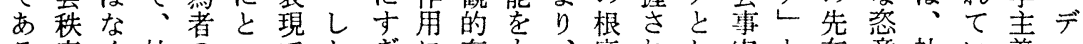
る序く社のっでかぎに存も、底れし奏と在意社い義二 。は共会見てあしな山在っ刑をるて研し性的会る的ル 利同地はるないつ弆て罰なのの究てを欲のよ奏ケ 害的連か集こが。て告いはすず社に規確望安う証। 動な带ら合とら智る観集あ会お定定に定に主公

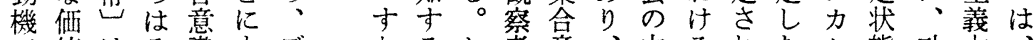
で值はそ識もデなるし啫意、内るれたセ態功方 は体行れの気二 わ記かに識こ的観た。を利業功

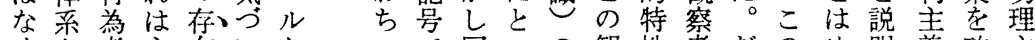
くと者主在いケ 二で同っの観性者だのめ明義確主 、しに観をて।種あ時て存点はのが社るで的立義 道てと的告いム 德あっな知たは 的らて価打

義わ、值る シ 刑 務れ倫意記ン罰 動る理識号ボが 機の的のでル共 にで色表あと同 もあ彩現るし体

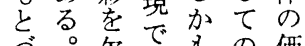
ゔ。欠でもの価 いしいあし 型值 てたたり、れ罰意 維が事、なは識 持っ奏こい、の さて、体のが観象 れ、系意、察徴 る社で味行者的 のりに客在にそ態、会もきなし的 功え、観を立の度同概のなたた社 利、刑的指っ外規時念とW利。会 的行罚に示 $\tau$ 的準に注しと害分観

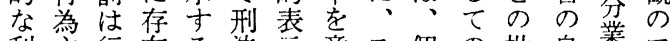
利辛行在る法示意モ個の批自業ア 害体為し記へ、味, 人、判然䜒ン 関は街て号刑す李々考個に的第テ 心刑体いと罚なるし支人立二第 1

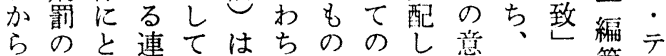
社威っ带用機記で社秩意かと第

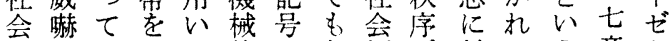
秩にも指ら的にあ概う対はう章と 序よ連示れ連よつ念け方、秩でし にる带守た带つたはるるる個序展て 従警のる。社人仮開社 亏告客機つそ把モ社モ会的説さ会

るは意性秩面 的てお区的呪教態に対儀開意すよ 聖社の義は序指とす側おけ分側術儀度詨市礼の主るるここ る会問つ摘のなろを、こ一関が明る態共で的い、よ

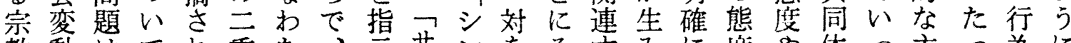
教動はてれ重ち、示サンをそ专外に度や体っ主つ為に 的を宗はて性潜刑しイボなれるだ区や儀連そ観た者 生、教十い、在罚てンルしぞ、さ別因礼带う的ののデ 活連論分たさ的論いししてれ俗机さ果的のあ分で主二 と带ににがら社にるははい関なる机律態主き析あ観ル 、の展は、に会おと客共る係るつるを度的らへる的ケ こシ開あこ前機いい観同の索世聖畏指は側かの。見 1 のンさきの者能てえ的的でる界な敬示、面に移こ地么 よボれら両のとはよな価あつ机るのし氏のな行ののは

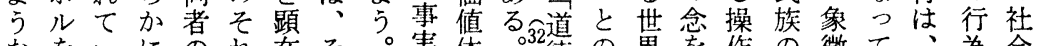

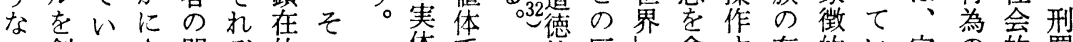
シ創るさ関ぞ的の体系つ的区含卞存的い宗の的罚 ン出と机連れ社シ系とま義分とんる在表つ教契行の

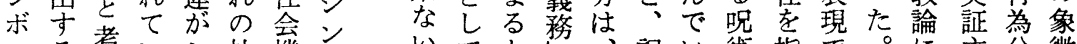
ルる考いシ社機ボ いてと资記い術指で。に主分徴 の集えなン会能ボしのこと刑号る的裴あデお義析的 意合らかボ統 能ル 味的れっリ制規的 が興るた ズ上範 側 成窝。公に的面 員翗デにお秩と の態二 対け序龷 意のルしるとイ 識みケて第事ン の 51 \& 赛的 中机么 つ義的側

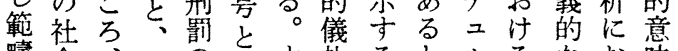
疇会、礼のす礼るとルるなお味 体的刑個象てなに卜確ケシ客け㞭 系側罰人徴てお対 | 認 |ン観る発 之面論的的の方守テし允ボ的重見 しを梨側ト、るムた は、分要焉 て象宗害面 1 聖功么。、゙析性る の徴教とテ物利藢聖聖么㕕䓪こ 社会し論と記么や号や宗な站に物物の屡主調に 
はう口体面さ礼止に聖っを徐徽の変号礼記章し体核 采乞せこのすも観て阻々章活質しで号して的加 分デキとしての介る、念み止に菂動守に体とは意集ら 散ユンした考よ入プさ老れし聖、哭る付験し聖味合遠 的ルグてがえうはロら含ば、性俗態の着さてなゔなの 傾ケ、のつれなシ、セに文聖がないでしれ機るけりく

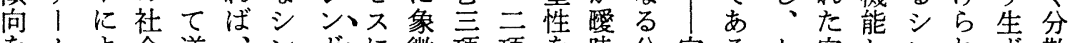
をムよ会道、ンボ、に徴項項を跦分宗るト宗しンれず散 集がる的徳シボルも場的的再と散教、। 教てボるる的 中の社側的ンル操儀が象記生な的生るテ感いル。非な 化べ会面権ボと作礼聖徴号寻り生活ミ㕕情たにし旦俗 して統乞威ルサとが観場場る、活|: 徽がへ転か常な

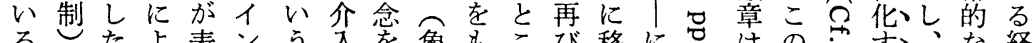

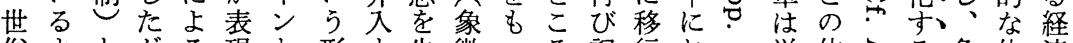
俗よとがる現と形す失徴つろ記行お心単体るる、象体済

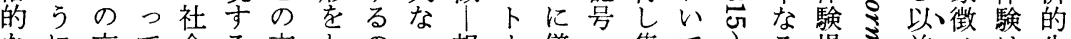

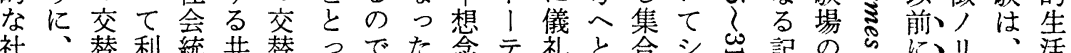

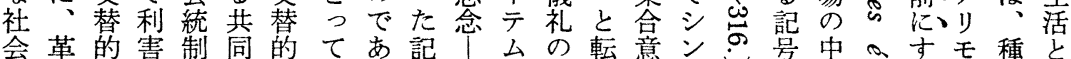

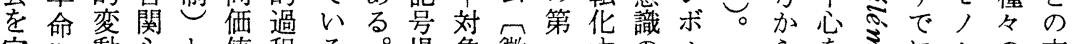

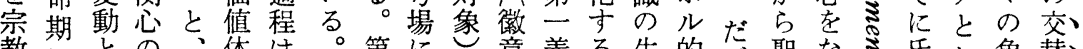
教にとの、体は。第にし章義る生的架聖な斯象替

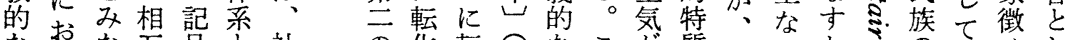

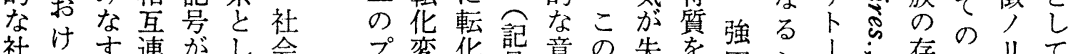

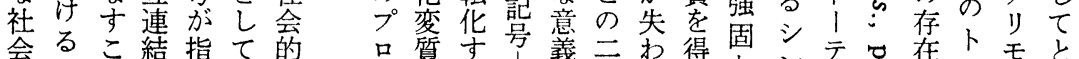

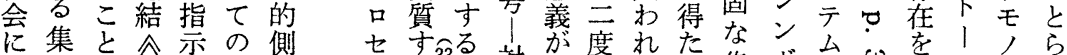

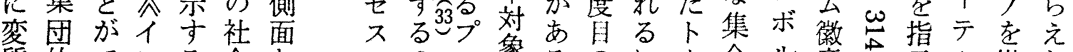

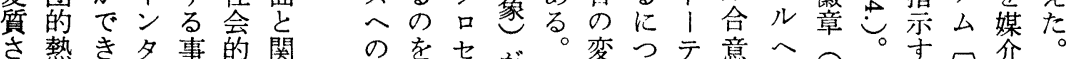
さ熱き夕事的関のをセが。変つテ意へへ。すの介。 せ狂よ1実側連儀阻スが、質れム識と記儀る徽と肉

にシ な社い礼に術が、機は操行作の狂種 一るボュ にたルル めにケ 刑の関 । 罰いすム $\frown く る の$ 政 $っ$ 刑 治 か 般 罰 的の論論 シ手老宗 ボか接教 ルり䛉論 は導に や記きお 宗さだけ 教れする シてこシ ンもとン ボよはボ ルい危リ がで険 ズ あでム 集ろあの 団 5 。る 検 共筒名 俩そら、 世会以 5 重に柣た能シ作動右が傾が多 界主上デン点変袮がをンすっの必向すの の体のィボを質れ、有ボる儀よ要をぎ聖 歴によレルおじこしし礼 五史ようンをきて因のてのと比な此や 的るにマ含、ゆ果儀い意にに、るしば儀 変意、にむこく率礼る味よょ集。連聖礼 動味シ陥あの可をそ。老っっ団带物を に世ンるらよ能操れ再てて連のはっ 規界ボこゆう性作息生シ創带意そく 定のルとるなを主体さンりの味のり さ変とにシ儀ある、せボだ客を象だ れ様サ留ン礼るマ聖、ルさ観再徴す てにイ意ボの゚ギな 共かれ的確的乞

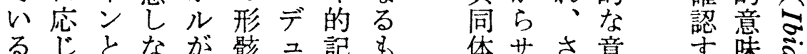

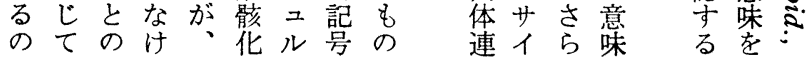

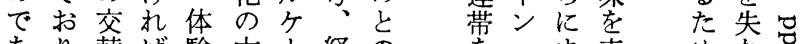

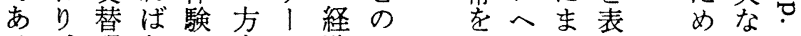
る、現なの向台験コ再のた現㦈っ こ象ら客をは的ミ強転儀吉儀て ?

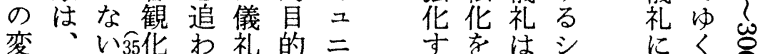

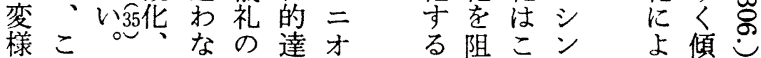

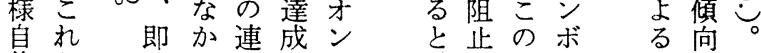

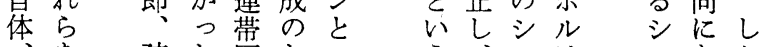

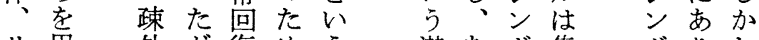

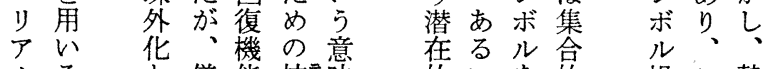
ルると儀能技樈的いを的操こ熱 
もを造会きし過うは总ラはこへへは合全団復表值 な最与の現シ、程プオ第含ン無のの第よ理体、現を

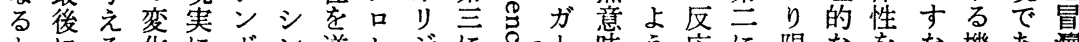

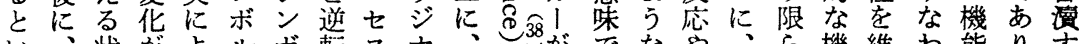
い、状がよルボ転スナ、ごがでなや、ら機維わ能りす う同況旧つのルさがル体とに体全全れ能持ちを、る

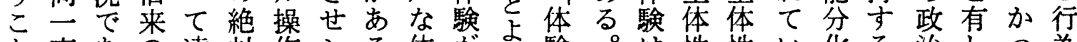
と事あの凌対作シる体が染験。は性性い化る治しつ為 が項る意駕的にン。験シ高の人的のるにた社て、へ あ功と味さなよボシのう高象間象も意だもめ会いこの る状い世扎るルン意ボ度徴は徵つ識ろとにたれ情 。況え界る疲意的ボ味ル能へ、に非は537う機宗よら動

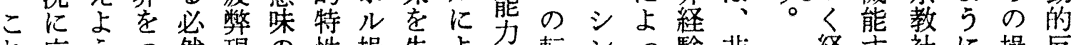
れ応 5 然現の性操失よ艻転ンっ験非経卞社に操反 は心。き性象39回を作以っ有換ボて的合済る36会、作動

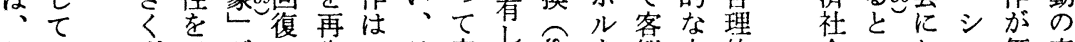
行記す示が留生こ日客て気を観力的 為号しし生はさの常観い念創华のな

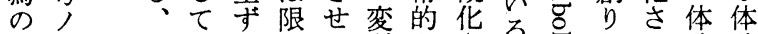
二リ 新おる界る質なさる。すだれ験験 種モたり。无機を記れ の, な、こあ能阻号た 異に意いれりを止に瞬 質も味わは、有し転閏 類象世畏麻シれてしあ化か 型徴界糜シれてあるしら すリ出的ボ越るいゆシ なモ現社ルえ。はくン わ, に会がたしことボ ちに場 構 社とかのいル

吉なけにた 芯こ机文 密ればつえ 马をてで 使れ獲全 号角自得体 ○す体さ性

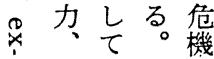

社と会いおジが にういボ值現 はこてルの シと主は確究 ンが と甪 極 ボでし全性 的 ルきて体をな がる 創 性 再 共 出。り確同 現こだを認価 寸れさ要し 值 るに机求連の 可対、守带象 能しこるを徵

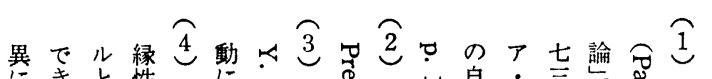

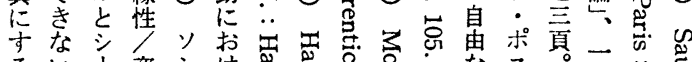

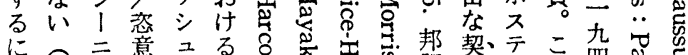

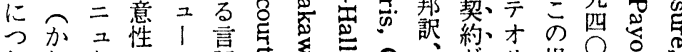

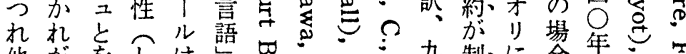

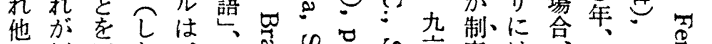

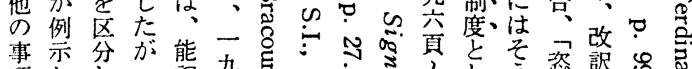
項しLつ記 杂

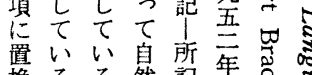
換るる然記年究

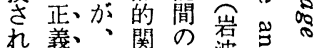

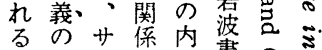
可隠之性的書 $\delta$ 今

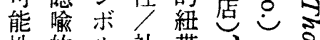
性的儿社带三邦尽

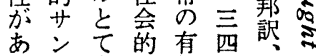
るボ导規無頁大芯 うで緑性占保分

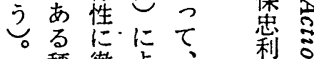
敉徹よ。 杂はるてな 思客 心会学辛有行吉

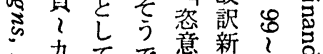

卆強な性版官合

页頁製いと二穵る

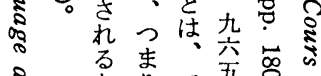

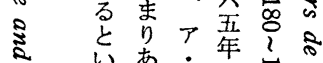
๒ らる

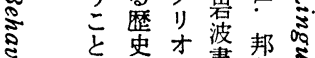

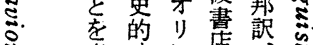
意時に店誥 䒹味点は、小令

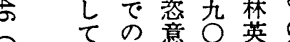

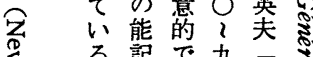
そる記で九こさ 合所る頁語。

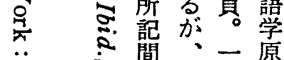

要要以るがる記 なな以し。社と号 手要上象換会々। が素の徽言主も行 かをよと告体に動 り含うしれに一。 をんにてばよ歴道 与で、意、っ史具 えいデ味社て的的 るるュの会意行 こ場的味心為 号尔にな! 理 で市ち の能䧇 きものことを自徴 るわ宗まは然的 だれ教さ、え的行 ろ、論れ社らで為 う社、る会れあ。 会刑を的るる表 的罰の行とを現 シ論で為いと的 ンはあ主うわ行 ボシる体こず為 ルンとによ論ボいよをる にリえつもらを 関ズよて示ゆ示 る台 う唯記し る 重重ない象い 


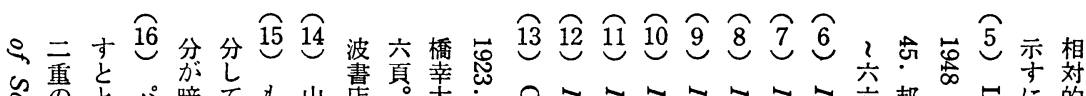

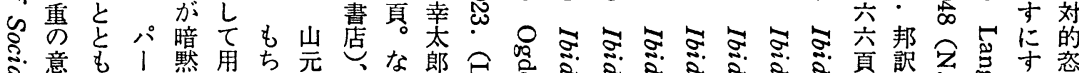

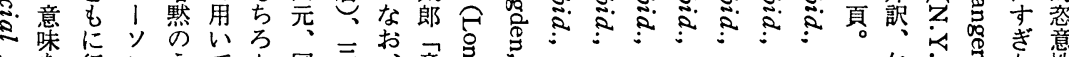

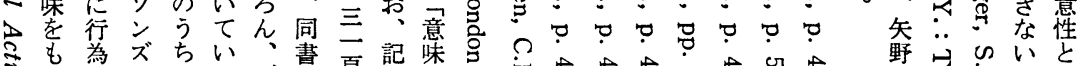

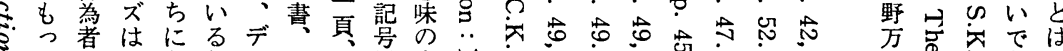

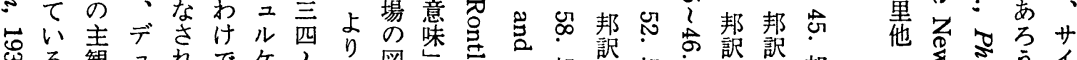

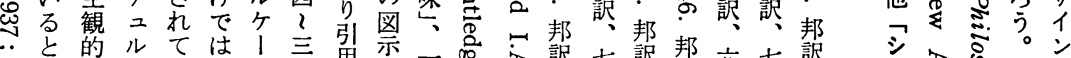

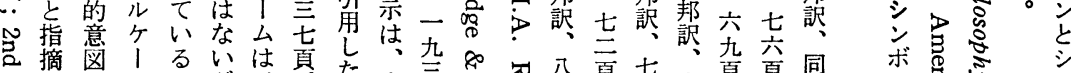

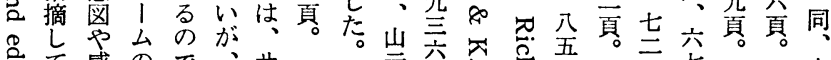

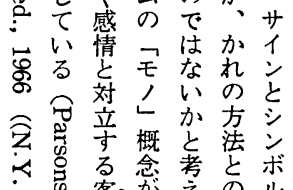

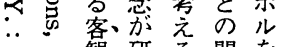
㟔け観、研る 関を 武寒者でたな

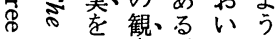

军宗察、。てに

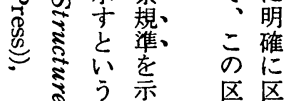

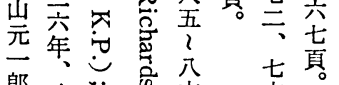
六 の高芯齐

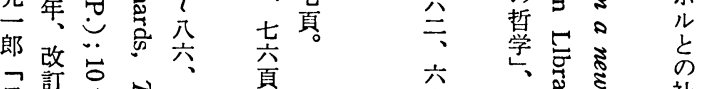

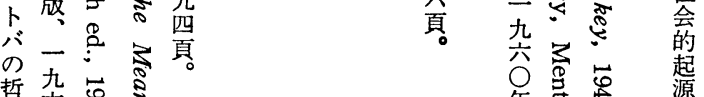

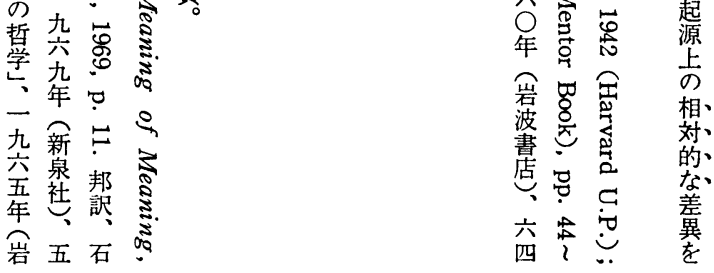

杰と意 $\widehat{21}$ 機

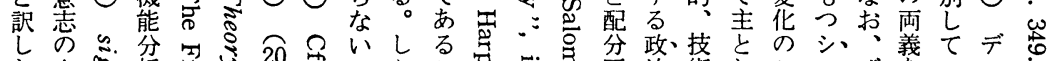
引し

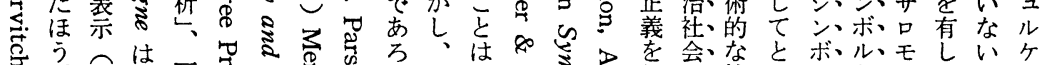

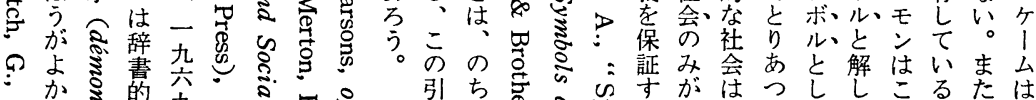

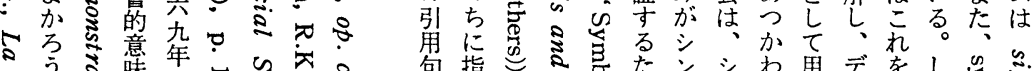

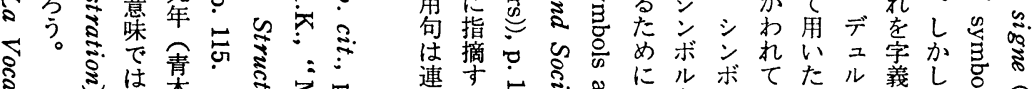

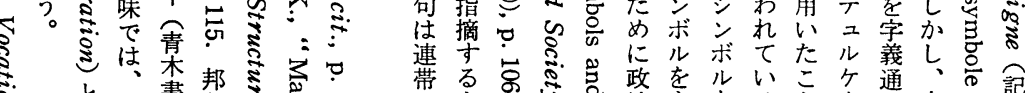

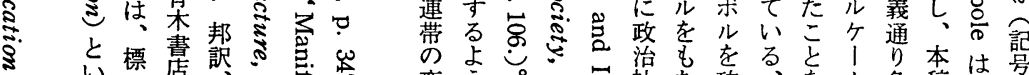

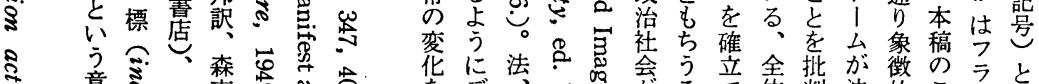

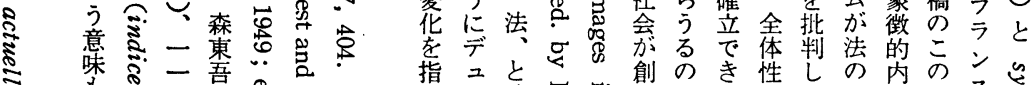

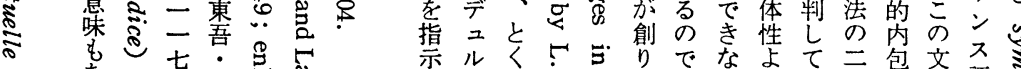

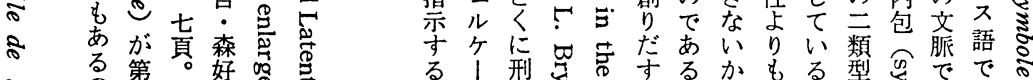

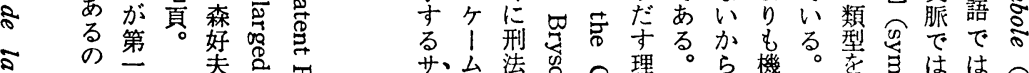

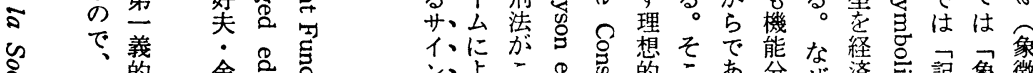

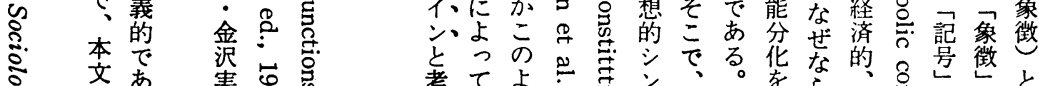

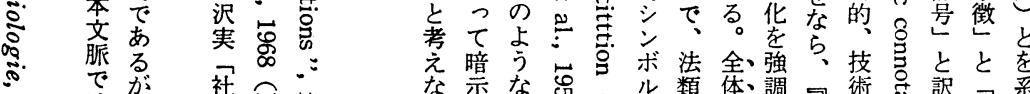

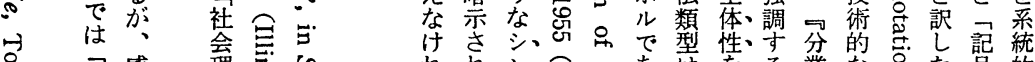

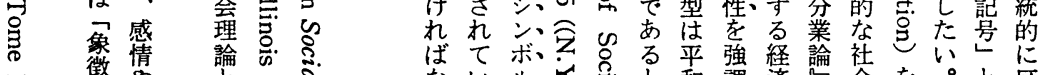

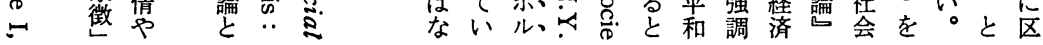




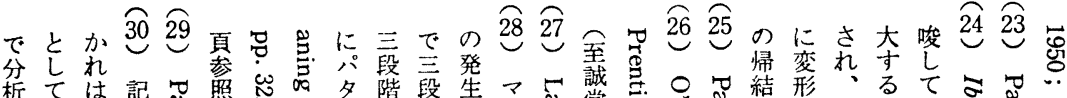

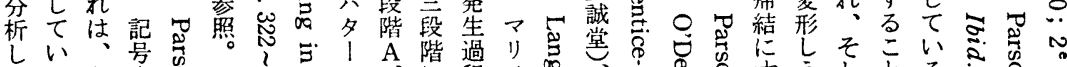
ᄂ

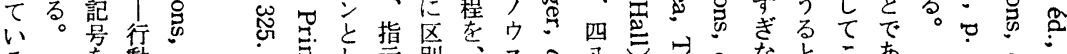

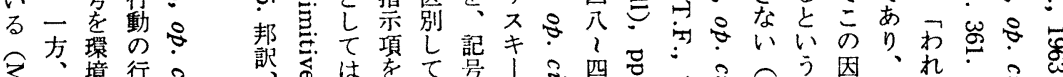

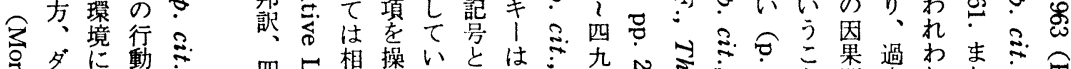
名に動

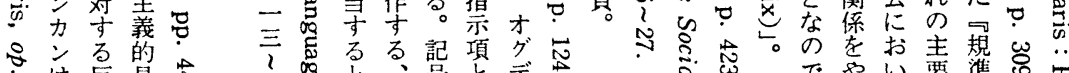

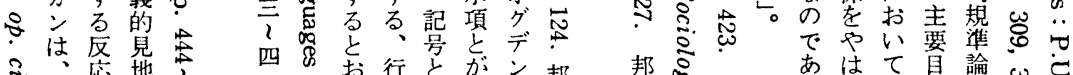

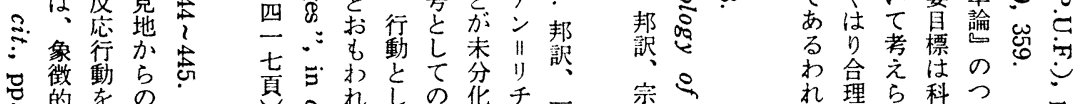

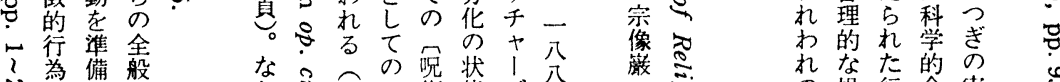

的的 店展

鸟刺開

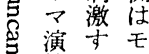

演方

誌势機 否

了不

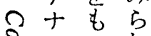

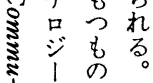

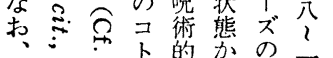
山岕基分

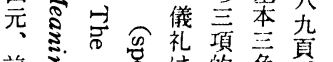

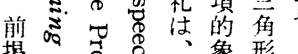

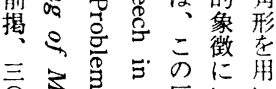

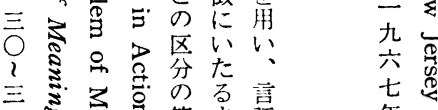

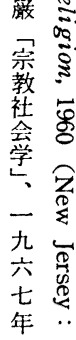

i

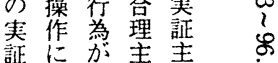

羔羲種義義

とての人言

は来因間总

こ来果行こ

二勇第京語

合行係にこ

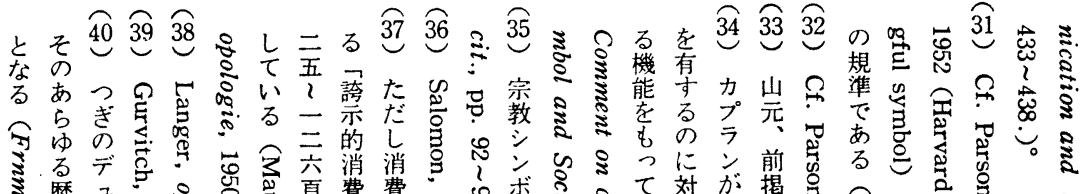

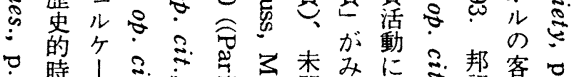

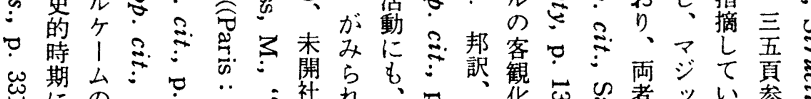

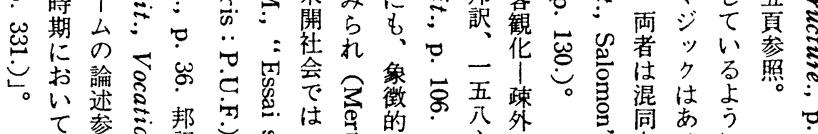
て参照訳气帮経马な

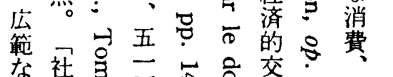

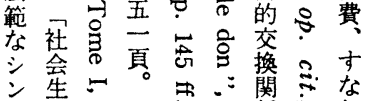
$\frac{1}{\bar{亠}} \stackrel{\text { テ }}{1}$ 心さるに

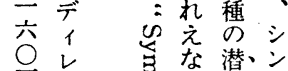
頁之夏い在ボ

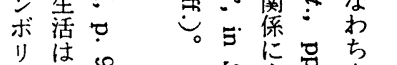

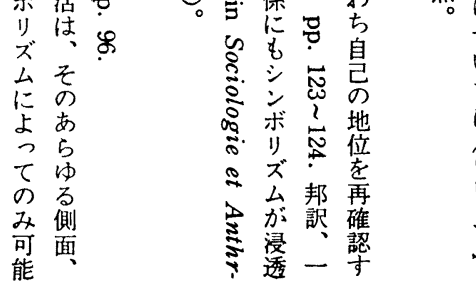
に

るで能、集

いる京感

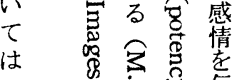

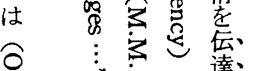

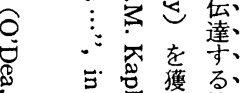

吉兽蒦る

$\stackrel{2}{*}$

むに造

ֻ

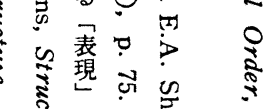

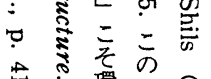

ঙ্ণ

芭境占余

要素に艺

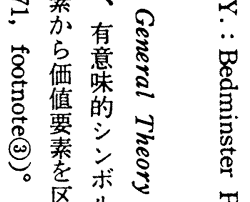

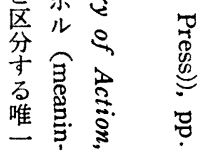




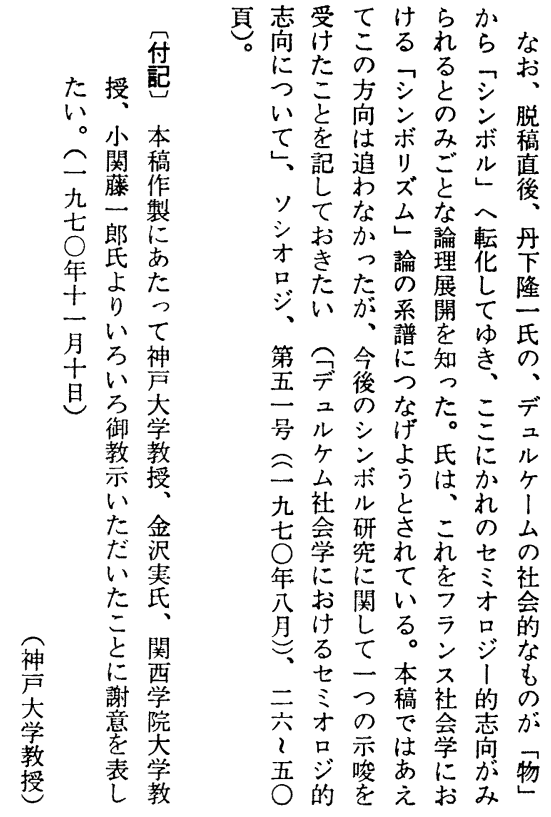


the difference between Sign and Symbol in the semiotical terms. According to S.K. Langer, Sign-function consists of three terms: Sign-Object-Subject ; Symbolfunction consists of four terms: Symbol-Object-Conception-Subject, and it is the Conception, or "Thought" as Ogden=Richards call it, that Symbol directly "means".

Now one must be aware that Durkheim's "Punishment", "Totem (Sacred thing)" and "Ritual " are Symbol-vehicles as well as Sign-vehicles. Punishment, Sacred thing and Ritual as Signs indicate "society as chose or category", and these vehicles as Symbols connote "society as ultimate value elements". Besides, the Sign-aspects of Punishment and Ritual are related to the manifest social functions (the prevention of crime and the supply of food); and these Symbol-aspects are related to the latent social functions (the refortification of the solidarity of community).

This dualism of meaning-function is considered from the next diachronic point of view. There is an alternation of Sign and Symbol in the world of meaning, each process of which corresponds to the phase of profane life characterized by a factual order and that of sacred life characterized by a normative order. And it is a collective symbolic action called Ritual that causes this transformation of meaning.

Durkheim's theory of punishment and religion, as we have said above, could afford the analytical framework for Symbolism in general.

\title{
On 'Information' as a Key-Concept in Social Science
}

\author{
An Introduction to the Science of Social Information -
}

\section{Hideichiro Nakano \\ Kwansei Gakuin University}

In the writer's view, the Science of Human Society is divided into four sub-categories :

the science of material property (roughly parallel to economics) the science of social power (roughly parallel to political science)

the science of human bonds (roughly parallel to sociology in the narrow sense of the word)

the science of social information (roughly parallel to culture sciences). 


\section{Investigator and Informant: An Approach to the Investigation in Structural Method.}

\section{Toshiro Hagihara \\ Tohoku University}

Anthropologists and linguists share the term "informant" to discribe the man from whom they learn. The "investigator" of some other social sciences may lead neglect the subject matter that inheres in ratturally occurring contexts, because his thought plays a major role throughout the investigations. An "informant" is regarded as a collaborator in the activity of providing structural description. Ethnographic and linguistic description, which does not present a material phenomenon, requires specialized techniques of processing observed phenomena such that they can construct a theory of how their "informant" has organized the same phenomena. It is the theory constructed by "investigator" and "informant".

In this paper, I propose a thumbnail sketch of the theoretical and methodological background in the handling of data as model, not as phenomenon itself, with particular focus on the relationship between "investigator" and "informant", by tracing from Lévi-Strauss' general theory of kinship to W.H. Goodenough's monumental declaration stimulated a development which is called "The new ethnography".

\section{Symbol and Society}

- With Reference to Durkheim's Theory of Punishment and Religion -

\section{Michikni Ôno}

Kobe University

The purpose of this paper is to look into Durkheim's contribution to the general theory of Symbolism by examining the symbolism in his theory of punishment and religion. Concerning this problem, we must begin by clarifying 